NASA/TM-2004-213343

\title{
Filtering and Control of High Speed Motor Current in a Flywheel Energy Storage System
}

Barbara H. Kenny and Walter Santiago

Glenn Research Center, Cleveland, Ohio 
Since its founding, NASA has been dedicated to the advancement of aeronautics and space science. The NASA Scientific and Technical Information (STI) Program Office plays a key part in helping NASA maintain this important role.

The NASA STI Program Office is operated by Langley Research Center, the Lead Center for NASA's scientific and technical information. The NASA STI Program Office provides access to the NASA STI Database, the largest collection of aeronautical and space science STI in the world. The Program Office is also NASA's institutional mechanism for disseminating the results of its research and development activities. These results are published by NASA in the NASA STI Report Series, which includes the following report types:

- TECHNICAL PUBLICATION. Reports of completed research or a major significant phase of research that present the results of NASA programs and include extensive data or theoretical analysis. Includes compilations of significant scientific and technical data and information deemed to be of continuing reference value. NASA's counterpart of peerreviewed formal professional papers but has less stringent limitations on manuscript length and extent of graphic presentations.

- TECHNICAL MEMORANDUM. Scientific and technical findings that are preliminary or of specialized interest, e.g., quick release reports, working papers, and bibliographies that contain minimal annotation. Does not contain extensive analysis.

- CONTRACTOR REPORT. Scientific and technical findings by NASA-sponsored contractors and grantees.
- CONFERENCE PUBLICATION. Collected papers from scientific and technical conferences, symposia, seminars, or other meetings sponsored or cosponsored by NASA.

- SPECIAL PUBLICATION. Scientific, technical, or historical information from NASA programs, projects, and missions, often concerned with subjects having substantial public interest.

- TECHNICAL TRANSLATION. Englishlanguage translations of foreign scientific and technical material pertinent to NASA's mission.

Specialized services that complement the STI Program Office's diverse offerings include creating custom thesauri, building customized databases, organizing and publishing research results ... even providing videos.

For more information about the NASA STI Program Office, see the following:

- Access the NASA STI Program Home Page at http://www.sti.nasa.gov

- E-mail your question via the Internet to help@sti.nasa.gov

- Fax your question to the NASA Access Help Desk at 301-621-0134

- Telephone the NASA Access Help Desk at 301-621-0390

- Write to:

NASA Access Help Desk

NASA Center for AeroSpace Information 7121 Standard Drive

Hanover, MD 21076 
NASA/TM-2004-213343

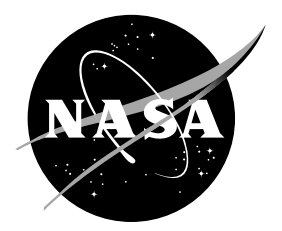

\section{Filtering and Control of High Speed Motor Current in a Flywheel Energy Storage System}

Barbara H. Kenny and Walter Santiago

Glenn Research Center, Cleveland, Ohio

Prepared for the

Second International Energy Conversion Engineering Conference

sponsored by the American Institute of Aeronautics and Astronautics

Providence, Rhode Island, August 16-19, 2004

National Aeronautics and

Space Administration

Glenn Research Center 
Available from

NASA Center for Aerospace Information 7121 Standard Drive

Hanover, MD 21076
National Technical Information Service 5285 Port Royal Road Springfield, VA 22100

Available electronically at http://gltrs.grc.nasa.gov 


\title{
Filtering and Control of High Speed Motor Current in a Flywheel Energy Storage System
}

\author{
Barbara H. Kenny and Walter Santiago \\ National Aeronautics and Space Administration \\ Glenn Research Center \\ Cleveland, Ohio 44135
}

\begin{abstract}
The NASA Glenn Research Center has been developing technology to enable the use of high speed flywheel energy storage units in future spacecraft for the last several years. An integral part of the flywheel unit is the three phase motor/generator that is used to accelerate and decelerate the flywheel. The motor/generator voltage is supplied from a pulse width modulated (PWM) inverter operating from a fixed DC voltage supply. The motor current is regulated through a closed loop current control that commands the necessary voltage from the inverter to achieve the desired current. The current regulation loop is the innermost control loop of the overall flywheel system and, as a result, must be fast and accurate over the entire operating speed range (20,000 RPM to 60,000 RPM) of the flywheel. The voltage applied to the motor is a high frequency PWM version of the DC bus voltage that results in the commanded fundamental value plus higher order harmonics. Most of the harmonic content is at the switching frequency and above. The higher order harmonics cause a rapid change in voltage to be applied to the motor that can result in large voltage stresses across the motor windings. In addition, the high frequency content in the motor causes sensor noise in the magnetic bearings that leads to disturbances for the bearing control. To alleviate these problems, a filter is used to present a more sinusoidal voltage to the motor/generator. However, the filter adds additional dynamics and phase lag to the motor system that can interfere with the performance of the current regulator. This paper will discuss the tuning methodology and results for the motor/generator current regulator and the impact of the filter on the control. Results at speeds up to $50,000 \mathrm{rpm}$ are presented.
\end{abstract}

\section{Nomenclature}

q-axis current (torque producing) in the rotor reference frame, amps

$\mathrm{d}$-axis current in the rotor reference frame, amps

Commanded motor phase voltage vector in rotor reference frame, volts

Commanded motor phase voltage vector in stator reference frame, volts

Motor phase current vector in the stationary reference frame, amps

Motor phase current vector in the rotor reference frame, amps

Estimated rotor angle, degrees

Estimated rotor speed, $\mathrm{rad} / \mathrm{sec}$

Motor/generator torque, N-m

Motor/generator back EMF constant, volt-sec

Inductance, henries

Capacitance, farads

Resistance, ohms

Integrator gain constant

Proportional gain constant

LaPlace operator

DC bus voltage, volts

Fundamental frequency, $\mathrm{Hz}$ 


\section{Introduction}

CLYWHEEL energy storage units are an attractive alternative to traditional batteries in space applications that require large numbers of charge / discharge cycles, wide operating temperature ranges, or peaking power for short periods. In addition, multiple flywheels can be used on a satellite to provide both energy storage and attitude control, thus combining two subsystems into one. Flywheels are composed of multiple subsystems including the high inertia flywheel rotor, the motor/generator, the magnetic bearings and the auxiliary bearings as shown in Fig. 1. The NASA Glenn Research Center has been developing advanced technologies for these subsystems over the last several years and has demonstrated energy storage at $60,000 \mathrm{rpm}$ with one unit and combined single axis attitude control and energy storage using two units $[1,2]$.

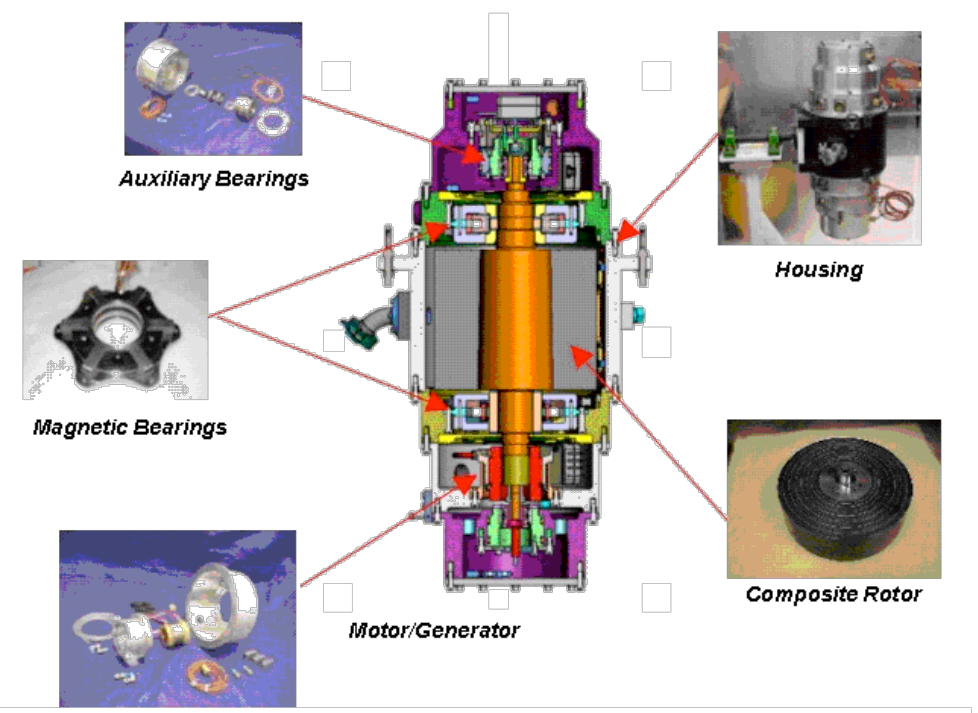

Figure 1. Flywheel Unit and Components

One important area of research is the development of the motor/generator controls. Algorithms have been developed to control the motor/generator such that the flywheel can store energy in charge mode and supply energy to loads in discharge mode while regulating the DC bus voltage [1]. Additional algorithms have been developed to combine the attitude control and energy storage functions of two separate flywheel units $[2,3]$. The innermost loop of the flywheel control for all of the algorithms is a current loop that is based on the field orientation control technique in which current is directly proportional to motor torque $[4,5]$. A block diagram of the field orientation control of the flywheel motor/generator is shown in Fig. 2.

In the field orientation technique, a mathematical transformation is performed on the current variables such that all of the control is done in a reference frame that is synchronous with the rotor. This allows the control quantities to become DC values and thus the bandwidth of the current regulator is not affected by the fundamental frequency of the machine. In addition, if the rotor reference frame $\mathrm{d}$-axis current, $\mathrm{i}_{\mathrm{ds}}^{\mathrm{r}}$, is regulated to zero, the machine torque becomes linearly proportional to the rotor reference frame q-axis current, $\mathrm{i}_{\mathrm{qs}}^{\mathrm{r}}$ as shown in Eq. (1) where $\square_{\mathrm{af}}$ is the back EMF constant of the machine. Thus the machine torque response is directly proportional to the current response.

$$
\mathrm{\square}_{\mathrm{m}}=\frac{3}{2} \square_{\mathrm{af}} \mathrm{i}_{\mathrm{qs}}^{\mathrm{r}}
$$

To perform the reference frame transformation properly, continuous rotor angular position feedback information is necessary. In typical industrial implementations, this information is provided by an additional sensor such as an encoder or a resolver. For the flywheel application, due to the high operating speed required, there is no position or speed sensor on the shaft. A "sensorless" position and speed estimation algorithm provides the necessary information by using the measured motor phase current values and the commanded motor voltage, $\mathbf{V}_{\mathrm{qds}}^{\mathrm{s}^{*}}$, values to continuously estimate rotor position and speed. This is described in detail in reference [6].

As the innermost loop of the entire flywheel control system, the algorithm shown in Fig. 2 must deliver a fast and accurate torque response over the entire

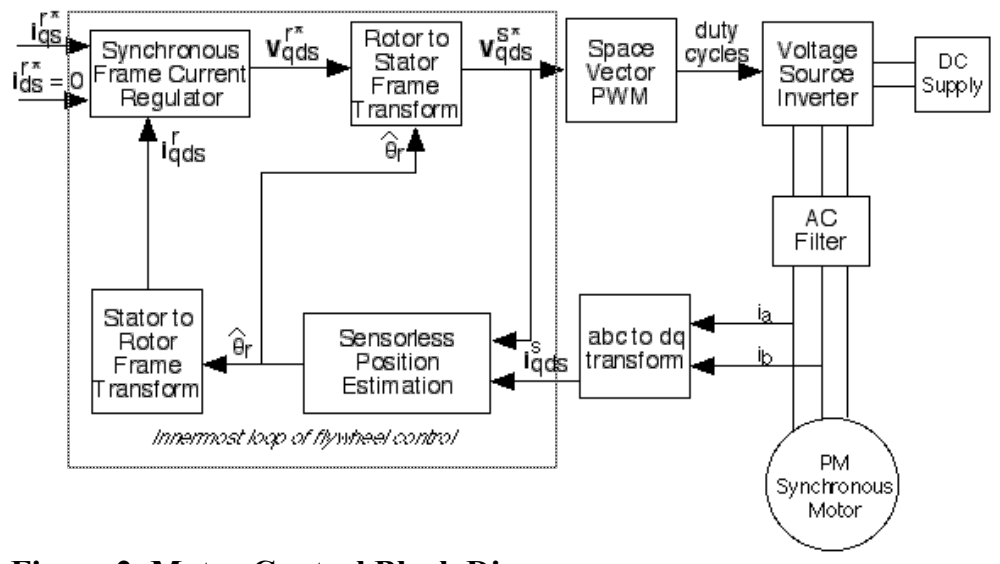

Figure 2. Motor Control Block Diagram 
operating speed range of the motor/generator. The key component to accomplishing this is the current regulator because the current is directly proportional to the torque as shown in Eq. (1). This paper discusses the current regulator performance with respect to the effect of the $\mathrm{AC}$ filter, proper tuning, and the operating speed with results presented for $20 \mathrm{kRPM}$ and $50 \mathrm{kRPM}$ operation (60,000 RPM was not demonstrated for this paper but has been documented previously $[7,8])$.

\section{AC Filter}

The AC filter is necessary in this application for a number of reasons. First of all, it reduces the $\mathrm{dv} / \mathrm{dt}$ stress that the motor winding sees due to the high frequency $(65 \mathrm{kHz})$ switching. Switching at a high frequency is necessary to

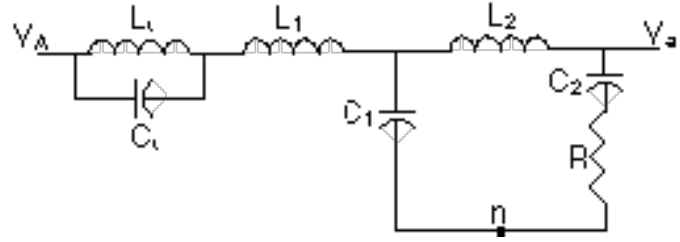

Figure 3. Filter Circuit Diagram

\begin{tabular}{|c|c|}
\hline Filter Component Name & Value \\
\hline $\mathrm{L}_{1}$ & $15 \square \mathrm{H}$ \\
\hline $\mathrm{L}_{2}$ & $7 \square \mathrm{H}$ \\
\hline $\mathrm{L}_{\mathrm{t}}$ & $76.12 \square \mathrm{H}$ \\
\hline $\mathrm{C}_{1}$ & $16.89 \square \mathrm{F}$ \\
\hline $\mathrm{C}_{2}$ & $36.19 \square \mathrm{F}$ \\
\hline $\mathrm{C}_{\mathrm{t}}$ & $.077 \square \mathrm{F}$ \\
\hline $\mathrm{R}$ & $.5 \square$ \\
\hline
\end{tabular}

Table 1. Filter Component Values create a high fidelity $1 \mathrm{kHz}$ fundamental frequency at the full speed value of 60,000 RPM. Secondly, the filter reduces the current ripple in the motor. The current ripple is significant without the filter because the machine inductance is relatively low. With the filter, this ripple is approximately $1 \mathrm{amp}$, peak to peak. It also reduces the common mode noise in both the motor and the magnetic bearings due to the parasitic capacitive coupling between the windings and the motor housing. The eddy current sensors used to sense the rotor shaft position for the magnetic bearings are particularly sensitive to high frequency noise. Further detailed discussion of the design and benefits of the AC filter can be found in [9].

The AC filter itself consists of two cascaded filters: a $65 \mathrm{kHz}$ "trap" filter tuned to reduce the harmonics at the switching frequency, and a four pole, two stage low pass filter tuned with a $10 \mathrm{kHz}$ corner frequency. The circuit diagram of one phase of the three phase filter is shown in Fig. 3. $\mathrm{V}_{\mathrm{A}}$ is the voltage at the inverter terminal, $\mathrm{V}_{\mathrm{a}}$ is the voltage at the motor terminal and $\mathrm{n}$ is the filter neutral. The motor neutral is not connected but the filter neutral is connected to the midpoint of the DC bus capacitor on the DC side of the inverter. The filter has the component values given in Table 1.

\section{Synchronous Frame Current Regulator}

The synchronous frame current regulator [10] shown in the block diagram in Fig. 2 consists of two PI controllers, each one acting on an axis of current, as shown in Figs. 4 and 5. The outputs of the current regulators result in a rotor reference frame voltage command that is converted to a phase voltage (line-neutral) command in the stationary reference frame. The conversion is accomplished using the estimated rotor angle, $\hat{\square}_{\mathrm{r}}$, as shown in Fig. 2. The commanded phase voltage is synthesized from the DC voltage by the high frequency pulse width modulation (PWM) switching of the inverter.

From a controls perspective, the simplest model of the motor is an R-L circuit in the rotor reference frame as described by Eqs. (2) and (3).

$$
\begin{aligned}
& \left.\frac{\mathrm{d} \mathbf{i}_{\mathrm{qs}}^{\mathrm{r}}}{\mathrm{dt}}=\frac{1}{\mathrm{~L}_{\mathrm{q}}}\right] \mathbf{V}_{\mathrm{qs}}^{\mathrm{r}}-\mathrm{R}_{\mathrm{s}} \mathbf{i}_{\mathrm{qs}}^{\mathrm{r}}= \\
& \left.\frac{\mathrm{di} \mathbf{d r}_{\mathrm{ds}}^{\mathrm{r}}}{\mathrm{dt}}=\frac{1}{\mathrm{~L}_{\mathrm{d}}}\right] \mathbf{V}_{\mathrm{ds}}^{\mathrm{r}}-\mathrm{R}_{\mathrm{s}} \mathbf{i}_{\mathrm{ds}}^{\mathrm{r}}=
\end{aligned}
$$

Using LaPlace variables and rearranging terms results in expressions for the transfer functions as shown in Eqs. (4) and (5) .

$$
\frac{\mathbf{i}_{\mathrm{qs}}^{\mathrm{r}}}{\mathbf{V}_{\mathrm{qs}}^{\mathrm{r}}}=\frac{\frac{1}{\mathrm{~L}_{\mathrm{q}}}}{\mathrm{s}+\frac{\mathrm{L}_{\mathrm{q}}}{\mathrm{R}_{\mathrm{s}}}}
$$

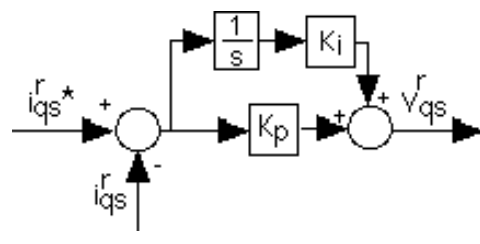

Figure 4. q-Axis Synchronous Frame Current Regulator

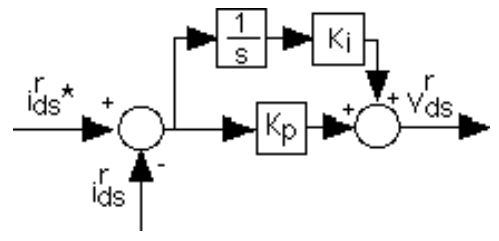

Figure 5. d-Axis Synchronous Frame Current Regulator 


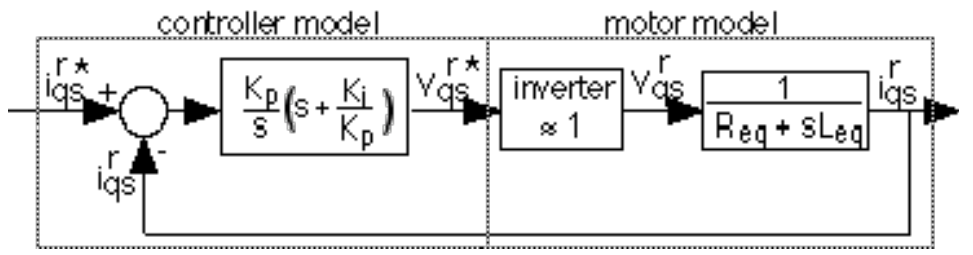

Figure 6. q-Axis Controller and Motor Block Diagram

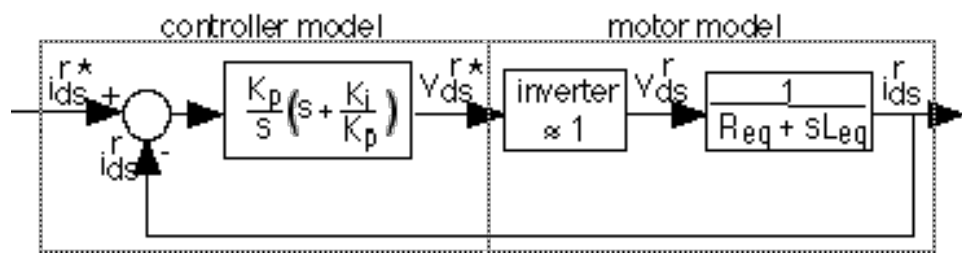

Figure 7. d-Axis Controller and Motor Block Diagram

$$
\frac{\mathbf{i}_{\mathrm{ds}}^{\mathrm{r}}}{\mathbf{V}_{\mathrm{ds}}^{\mathrm{r}}}=\frac{\frac{1}{\mathrm{~L}_{\mathrm{d}}}}{\mathrm{s}+\frac{\mathrm{L}_{\mathrm{d}}}{\mathrm{R}_{\mathrm{s}}}}
$$

The motor model can now be combined with the current regulator model into one block diagram so that the initial tuning of the regulator can be found as shown in Figs. (6) and (7). The PI current regulator has been rewritten in a form to show the zero of the controller and the inverter is modeled with a transfer function of 1 . Note that with the simple R-L model of the motor in the rotor reference frame, there is no coupling between the d- and q- axes.

The simple inverter model with a transfer function equal to 1 is reasonably accurate for the fundamental frequencies as long as the magnitude of the commanded voltage does not exceed a maximum value that is dependent on the DC bus voltage magnitude and the modulation technique. The magnitude of the commanded voltage is given in Eq. (6) and is the same in both the rotating and stationary reference frames. The modulation technique used in the flywheel system is known as space vector modulation. For this modulation technique, the maximum commanded voltage magnitude that allows the inverter to remain in the linear region of control (transfer function equal to 1) is given in Eq. (7) [11].

$$
\begin{gathered}
\left|\mathbf{V}_{\mathrm{qds}}^{\mathrm{r}^{*}}\right|=\sqrt{\left(\mathbf{V}_{\mathrm{qs}}^{\mathrm{r} *}\right)^{2}+\left(\mathbf{V}_{\mathrm{ds}}^{\mathrm{r} *}\right)^{2}}=\left|\mathbf{V}_{\mathrm{qds}}^{\mathrm{s}^{*}}\right|=\sqrt{\left(\mathbf{V}_{\mathrm{qs}}^{\mathrm{s}^{*}}\right)^{2}+\left(\mathbf{V}_{\mathrm{ds}}^{\mathrm{s}^{*}}\right)^{2}} \\
\left|\mathbf{V}_{\mathrm{qds}}^{\mathrm{r}^{*}}\right| \leq \mathrm{V}_{\max }=\frac{\mathrm{V}_{\mathrm{dc}}}{\sqrt{3}}
\end{gathered}
$$

Based on Figs. 6 and 7, the transfer function of the q- and d-axis currents are given in (8) and (9), respectively.

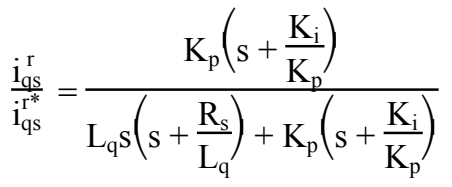

$$
\begin{aligned}
& \frac{i_{d s}^{r}}{i_{d s}^{r^{*}}}=\frac{K_{p} \beta+\frac{K_{i}}{K_{p}}}{\left.L_{d} s-\frac{R_{s}}{\beta}=+K_{p}=\frac{K_{i}}{L_{d}}\right]}
\end{aligned}
$$

For the purpose of tuning the current regulator, $\mathrm{L}_{\mathrm{s}}$, the average of the $\mathrm{d}$ - and q-axis inductances, is used. With this in mind, if the gains in Eqs. (8) and (9) are set according to Eq. (10), then the transfer functions reduce to the values shown in Eqs. (11) and (12).

$$
\begin{gathered}
\frac{\mathrm{R}_{\mathrm{s}}}{\mathrm{L}_{\mathrm{s}}}=\frac{\mathrm{K}_{\mathrm{i}}}{\mathrm{K}_{\mathrm{p}}} \\
\frac{\mathrm{i}_{\mathrm{qs}}^{\mathrm{r}}}{\mathrm{i}_{\mathrm{qs}}^{\mathrm{r}^{*}}}=\frac{\mathrm{K}_{\mathrm{p}}}{\mathrm{L}_{\mathrm{s}}} \frac{1}{\frac{\mathrm{G}}{\mathrm{s}}+\frac{\mathrm{K}_{\mathrm{p}}}{\mathrm{L}_{\mathrm{s}}}} \\
\frac{\mathrm{i}_{\mathrm{ds}}^{\mathrm{r}}}{\mathrm{i}_{\mathrm{ds}}^{\mathrm{r}^{*}}}=\frac{\mathrm{K}_{\mathrm{p}}}{\mathrm{L}_{\mathrm{s}}} \frac{1}{\mathrm{G}+\frac{\mathrm{K}_{\mathrm{p}}}{\mathrm{L}_{\mathrm{s}}}}
\end{gathered}
$$

The bandwidth of the response can then be set according to Eq. (13) with the selection of $\mathrm{K}_{\mathrm{p}}$ which sets the poles of Eqs. (11) and (12) to the desired location. The bandwidth in this equation corresponds to the response of the motor torque and is theoretically independent of the fundamental frequency and operating speed of the machine. 


$$
\mathrm{f}_{\mathrm{bw}}=\frac{\mathrm{K}_{\mathrm{p}}}{2 \square \mathrm{L}_{\mathrm{s}}} \mathrm{Hz}
$$

Generally, the phase resistance and inductance of the motor are used in Eqs. (10) through (13) to calculate the current regulator gains and bandwidth. Even if perfect pole-zero cancellation is not achieved in Eqs. (8) and (9), either the response is adequate for a particular application, or the gains can be tuned heuristically starting from the calculated values until the desired response is achieved. However, if the filter introduces a large impedance into the circuit, the response can be significantly different than expected. The initial tuning can be improved by modifying the inductance and resistance values used in Eqs. (10) through (13) to include the effect of the filter impedance.

The filter impedance can be calculated using a Thevenin equivalent impedance approach and the circuit diagram of Fig. 3. The Thevenin equivalent voltage is basically the fundamental voltage from the inverter with significantly reduced $65 \mathrm{kHz}$ switching content and harmonics. It has very little phase lag or magnitude change within the operating frequency range $(0-1000 \mathrm{~Hz})$ as discussed in [9]. The Thevenin equivalent impedance of the filter shown in Fig. 3 is a $6^{\text {th }}$ order equation that is given in the Appendix. At the frequencies of interest, however, it is predominantly inductance, and this is most easily seen by actually measuring the impedance of the circuit using an impedance analyzer and then calculating the equivalent inductance and resistance. Three possible circuit configurations were measured: the motor only, the motor with the two stage filter of Fig. 3 but without the L-C trap portion, and the motor with the entire filter of Fig. 3. The results are given in Table 2.

\begin{tabular}{|c|c|c|c|c|c|c|}
\hline \multirow{2}{*}{$\begin{array}{l}\text { Frequency } \\
\qquad(\mathrm{Hz})\end{array}$} & \multicolumn{2}{|c|}{ Motor Only } & \multicolumn{2}{|c|}{$\begin{array}{c}\text { Motor plus filter without } \\
\text { trap } \\
\end{array}$} & \multicolumn{2}{|c|}{$\begin{array}{l}\text { Motor plus filter with trap } \\
\text { (Fig. 3) }\end{array}$} \\
\hline & $\mathrm{R}_{\mathrm{eq}}(\mathrm{m} \square)$ & $\mathrm{L}_{\mathrm{eq}}(\square \mathrm{H})$ & $\mathrm{R}_{\mathrm{eq}}(\mathrm{m} \square)$ & $\mathrm{L}_{\mathrm{eq}}(\square \mathrm{H})$ & $\mathrm{R}_{\mathrm{eq}}(\mathrm{m} \square)$ & $\mathrm{L}_{\mathrm{eq}}(\square \mathrm{H})$ \\
\hline 100 & 33 & 39 & 66 & 64 & 84 & 140 \\
\hline 200 & 36 & 38 & 68 & 63 & 87 & 139 \\
\hline 300 & 38 & 37 & 71 & 62 & 90 & 138 \\
\hline 400 & 41 & 37 & 74 & 62 & 94 & 138 \\
\hline 500 & 44 & 36 & 78 & 62 & 99 & 137 \\
\hline 600 & 47 & 36 & 82 & 62 & 104 & 137 \\
\hline 700 & 50 & 35 & 87 & 62 & 109 & 137 \\
\hline 800 & 54 & 35 & 93 & 62 & 116 & 137 \\
\hline 900 & 57 & 34 & 99 & 62 & 122 & 137 \\
\hline 1000 & 60 & 34 & 106 & 62 & 130 & 137 \\
\hline Average & 46 & 36 & 82 & 62 & 104 & 138 \\
\hline
\end{tabular}

Table 2. Circuit Resistance and Inductance Values Calculated from Impedance Measurements.

Based on the measured resistance and inductance, two sets of gains can be calculated for various bandwidths using (10) and (13) as shown in Table 3.

\begin{tabular}{|c|c|c|c|c|c|c|}
\hline \multirow[t]{2}{*}{ Bandwidth } & \multicolumn{2}{|c|}{ Motor Only Parameters } & \multicolumn{2}{|c|}{$\begin{array}{c}\text { Motor plus two stage filter (no } \\
\text { L-C trap) }\end{array}$} & \multicolumn{2}{|c|}{$\begin{array}{c}\text { Motor plus two stage } \& \\
\text { trap filter (Fig. } 3 \text { ) }\end{array}$} \\
\hline & $\underline{K_{p}}$ & $\underline{\underline{K_{i}}}$ & $\underline{\mathrm{K}_{\mathrm{p}}}$ & $\underline{\mathrm{K}_{\mathrm{i}}}$ & $\underline{\mathrm{K}_{p}}$ & $\underline{\mathrm{K}_{\mathrm{i}}}$ \\
\hline $1 \mathrm{kHz}$ & .2 & 544 & .39 & 515 & .87 & 654 \\
\hline $1.5 \mathrm{kHz}$ & .3 & 820 & .58 & 773 & 1.3 & 976 \\
\hline $2 \mathrm{kHz}$ & .4 & 1088 & .78 & 1030 & 1.73 & 1308 \\
\hline
\end{tabular}

Table 3. Current Regulator Gains for Various Bandwidths.

\section{Experimental Results}

For all of the experimental results, the two stage with L-C trap filter (Fig. 3) was used between the output of the inverter and the motor as shown in Fig. 2. However, the first two sets of results presented herein use current regulator gains based on the motor parameters alone, without consideration of the effect of the filter. The performance consequences of not including the filter impedance in calculating the gains can then be seen. The rest of the results use the gains based on the entire circuit impedance measurement: motor plus two stage and L-C trap filter (the last two columns of Table 3). All of the results use the gains calculated for a $2 \mathrm{kHz}$ bandwidth.

Two speeds within the operating range of the flywheel system, 20,000 RPM and 50,000 RPM, were tested. In general, either set of gains worked well at 20,000 RPM. The response was fast and there was very little overshoot or 


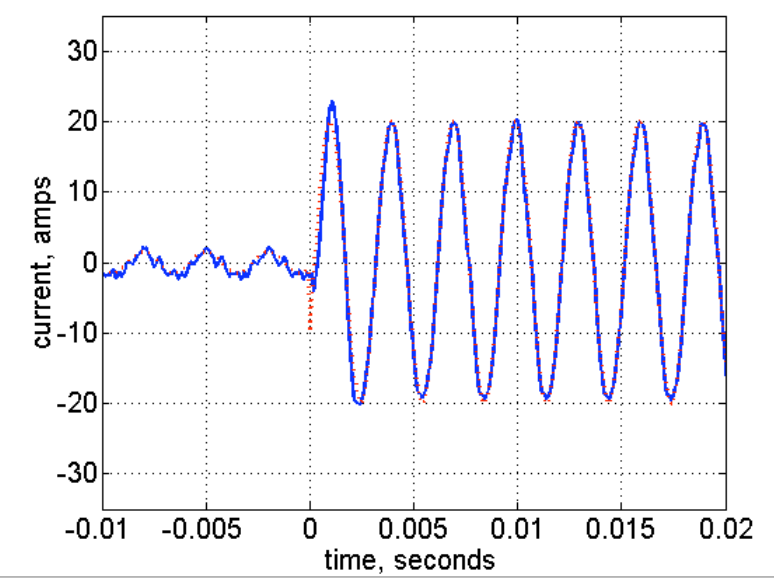

Figure 8: Motor Phase Current Response to Step Change in q-Axis Current Command at 20 kRPM.

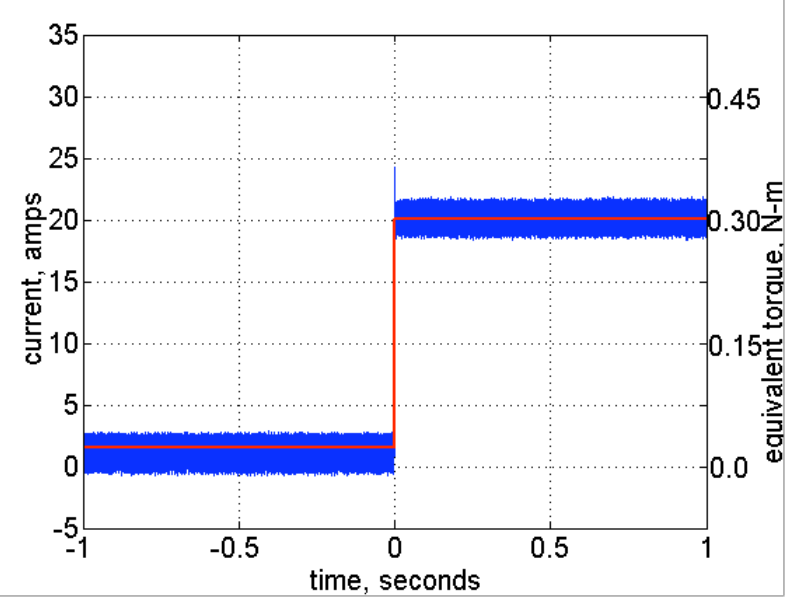

Figure 9. Motor Commanded (red) and Actual (blue) q-axis Current and Equivalent Torque at 20 kRPM.

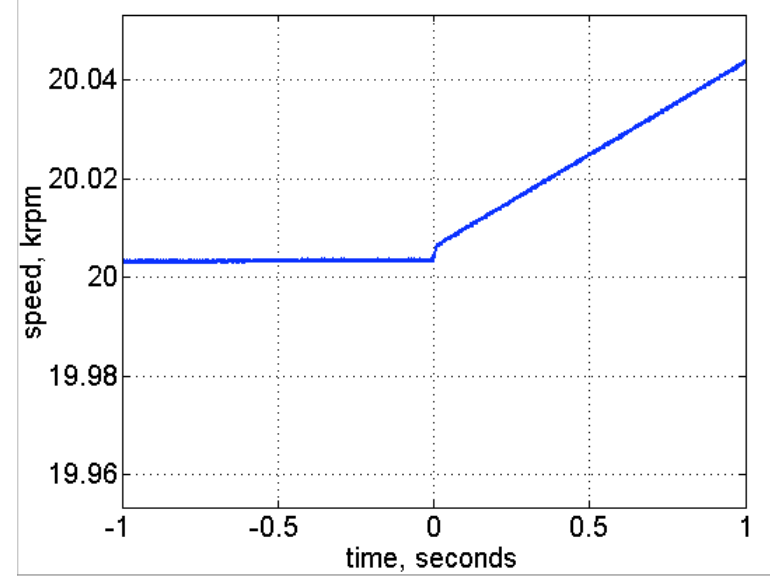

Figure 11. Motor Speed for Step Change in Commanded Current at Time $t=0$ at 20 kRPM. oscillation. In contrast, operation at 50,000 RPM was more challenging and required modifications of the controller to achieve the desired performance. To best demonstrate the performance improvements resulting from the control modifications, the subsequent data presented is at 50,000 RPM. The control modifications also improve performance at low speeds but the improvement is more evident at higher speeds and thus the high speed data is presented herein.

Figures 8 through $12^{*}$ show 20,000 RPM operation using the motor alone gain parameters. Figure 8 shows the phase current response to a step change command in motor q-axis current from 1.5 amps to 20 amps. Figures 9 and 11 show the motor q-axis current (and estimated torque) and the motor speed. The motor accelerates at a constant rate after the step change, indicating a constant motor torque as shown on Fig. 11.

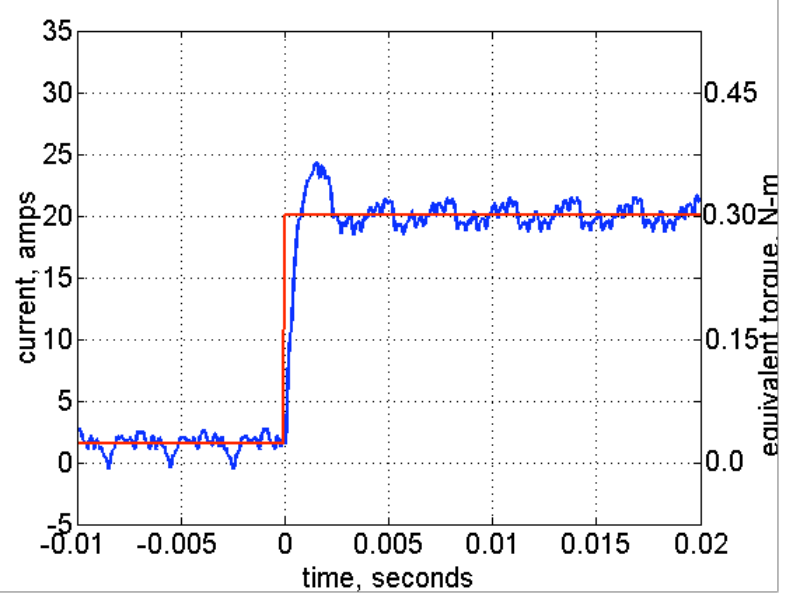

Figure 10. Expanded Scale of Motor q-axis Current Response at $20 \mathrm{kRPM}$.

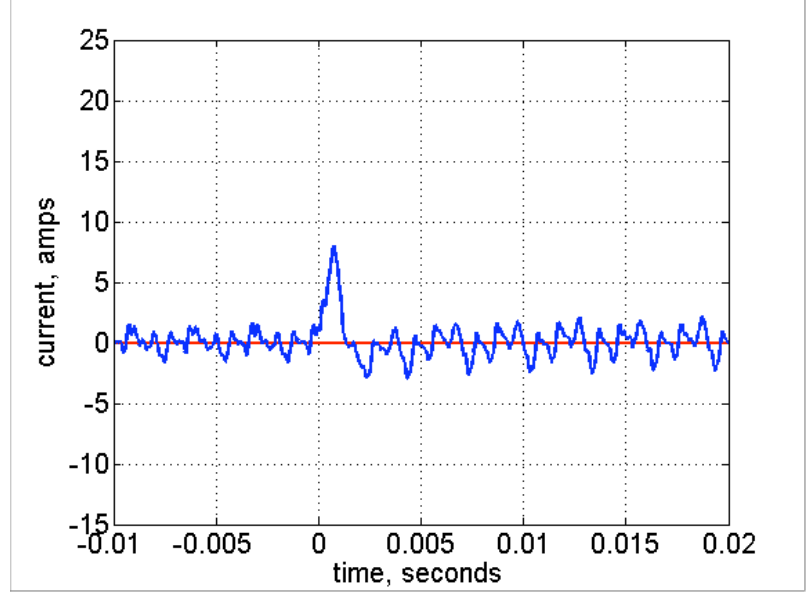

Figure 12. Expanded Scale of Motor d-axis Current Response at $20 \mathrm{kRPM}$.

\footnotetext{
*In all of the plots in this paper, the red trace is the commanded value and the blue trace is the measured value.
} 


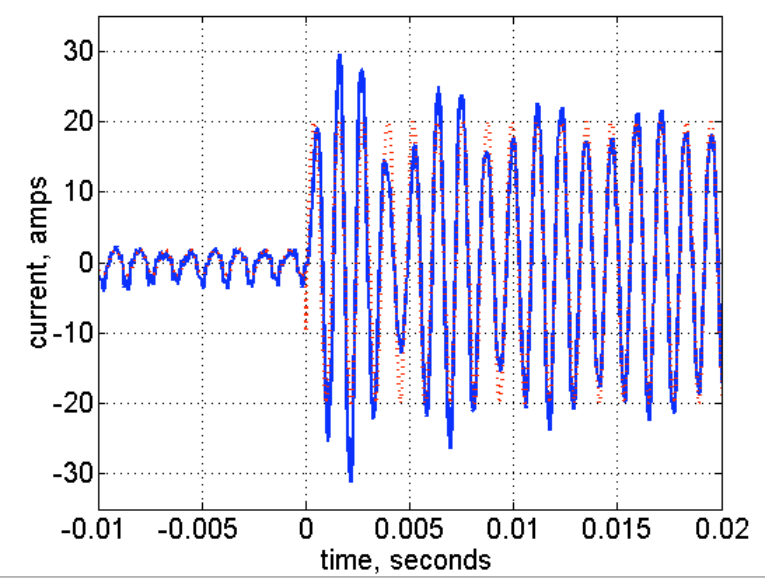

Figure 13. Motor Phase Current Response to Step Change in q-Axis Current Command at 50 kRPM.

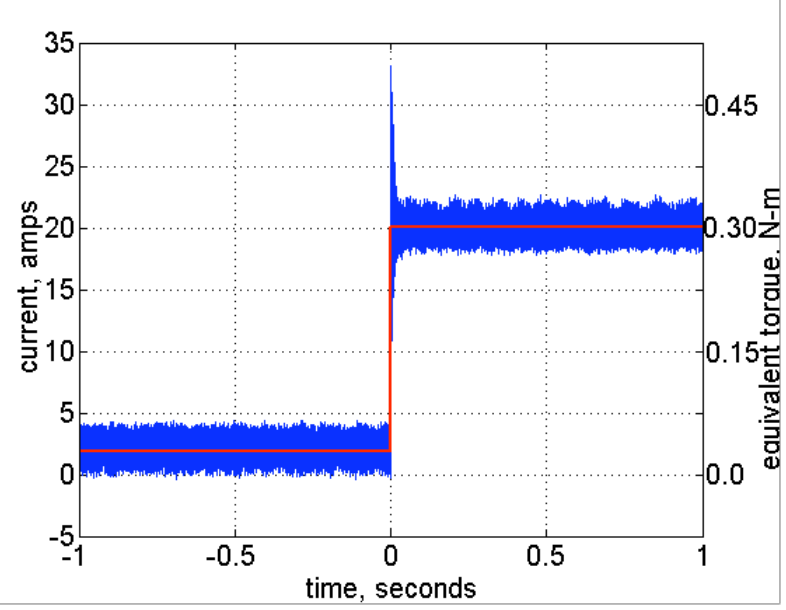

Figure 14. Motor Commanded and Actual q-axis Current and Equivalent Torque at $50 \mathrm{kRPM}$.

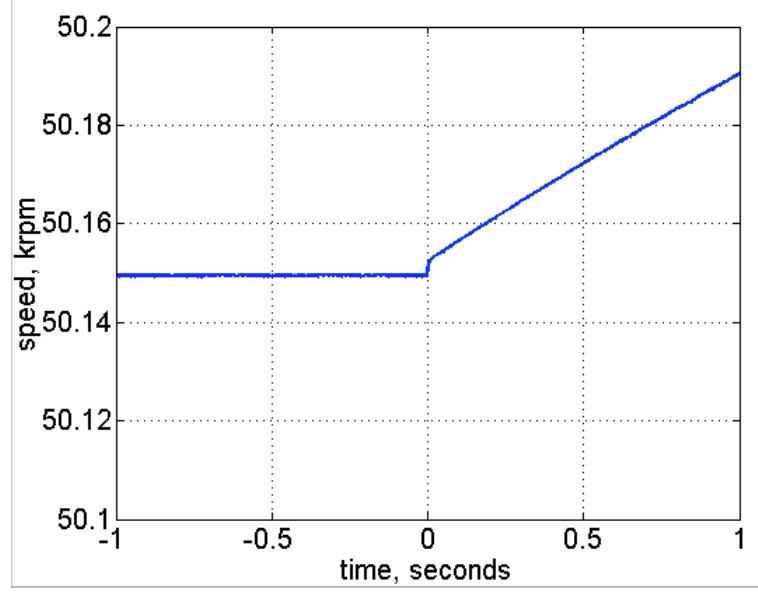

Figure 16. Motor Speed for Step Change in Commanded Current at Time $t=0$ at $50 \mathrm{kRPM}$.
Figures 10 and 12 show an expanded time scale version of the q-and d-axis current response. It can be seen that the q-axis current rises to the commanded level with a response time on the order of $2 \mathrm{kHz}$ but with some overshoot. The d-axis current exhibits a disturbance when the q-axis step change occurs. This is due to coupling between the d- and q-axes that is not accounted for in the simple R-L model of the motor and will be discussed in Section V.

Figures 13 through 17 give the results at 50,000 RPM, again using the gains based only on the motor parameters. This corresponds to an $833 \mathrm{~Hz}$ fundamental frequency of current and voltage. It can be seen that at this speed there is significant oscillation as the current reaches the commanded value. Figure 15 shows that the overshoot of the q-axis current reaches almost $150 \%$ of the commanded value and the oscillation takes over $20 \mathrm{msec}$. to dampen out. The

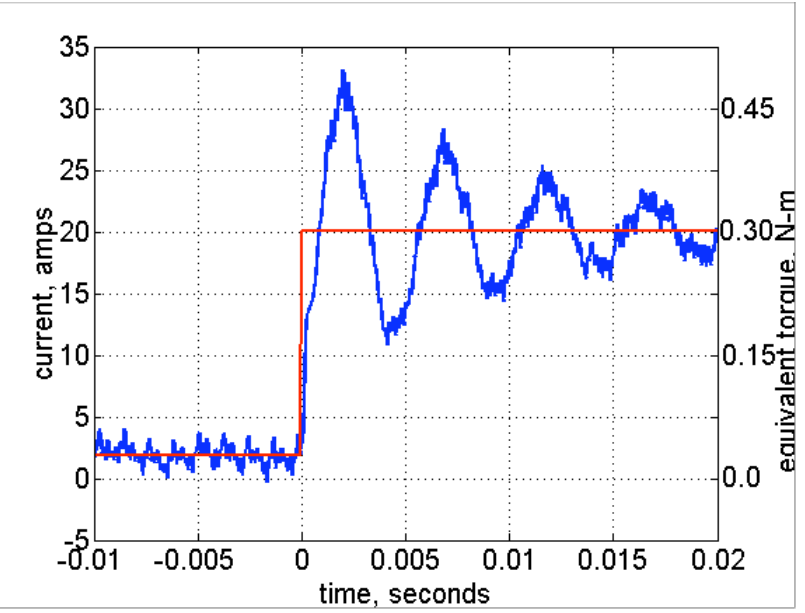

Figure 15. Expanded Scale of Motor q-axis Current Response at $50 \mathrm{kRPM}$.

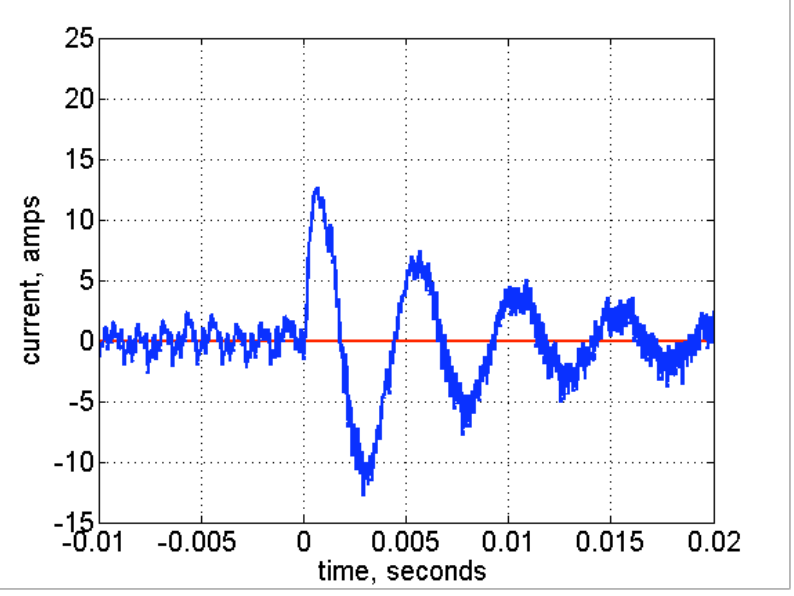

Figure 17. Expanded Scale of Motor d-axis Current Response at $50 \mathrm{kRPM}$. 


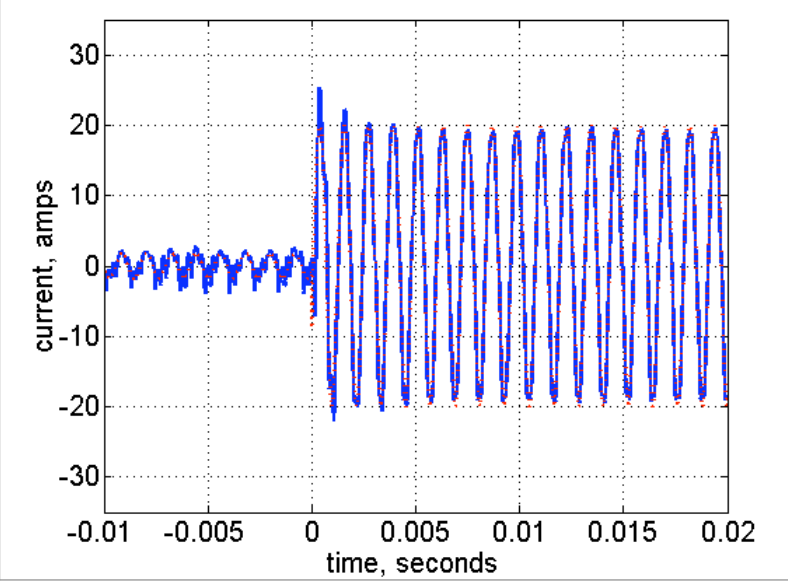

Figure 18. Motor Phase Current Response at 50 kRPM, with Filter Gains.

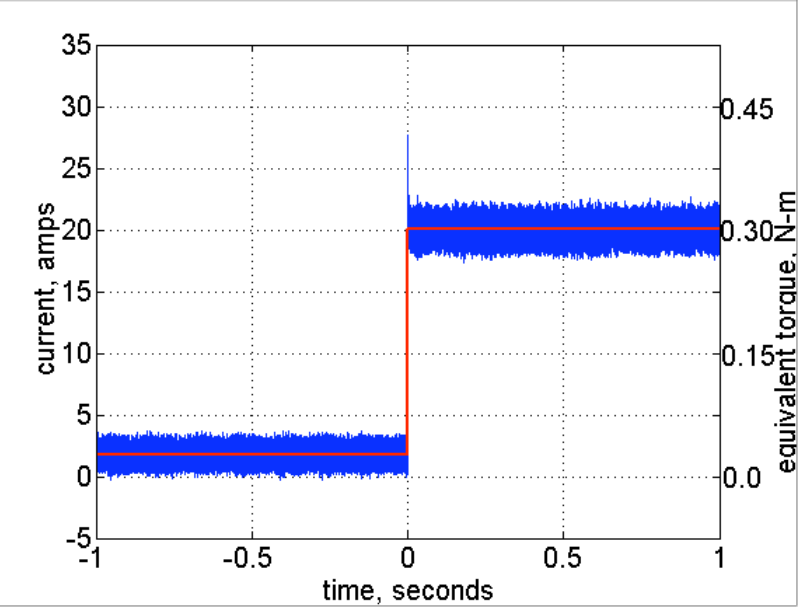

Figure 19. Motor Commanded and Actual q-axis Current and Equivalent Torque at 50 kRPM with Filter Gains.

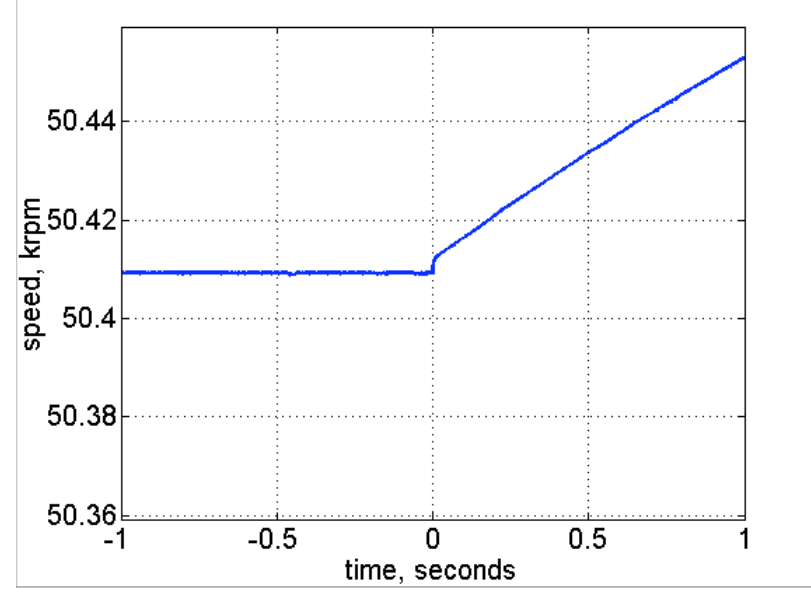

Figure 21. Motor Speed during transient at 50 kRPM with Filter Gains. current regulator performance using the motor parameters only gains is not acceptable at high speeds and may even become unstable for larger disturbances. In contrast, Figs. 18 through 22 show the current regulator performance at 50,000 RPM using the gains calculated with the total measured impedance (motor plus the two stage filter with L-C trap, Fig. 3, and a 2 $\mathrm{kHz}$ bandwidth from Table 3 ). The overshoot is still present but it is reduced in magnitude and there is no period of extended oscillation. The q-axis current settles to the commanded value in less than $5 \mathrm{msec}$. and the rise time is very fast, achieving the desired 2 $\mathrm{kHz}$ bandwidth. However, the $\mathrm{d}$-axis current still exhibits a large transient during the step change in the q-axis command. This transient can be reduced by augmenting the current regulator to compensate for the cross coupling between the q- and d-axes that is not represented in the simple models of Eqs. (4) and (5)

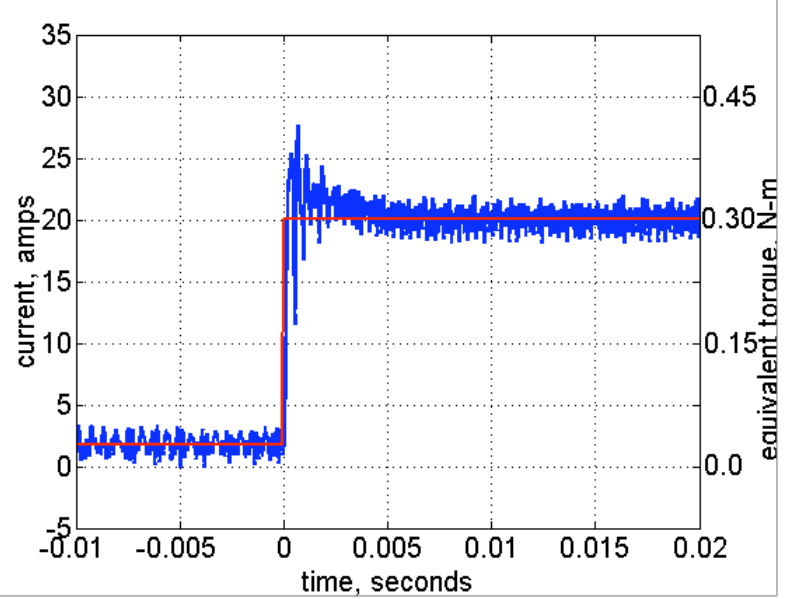

Figure 20. Expanded Motor q-axis Current Response at 50 kRPM with Filter Gains.

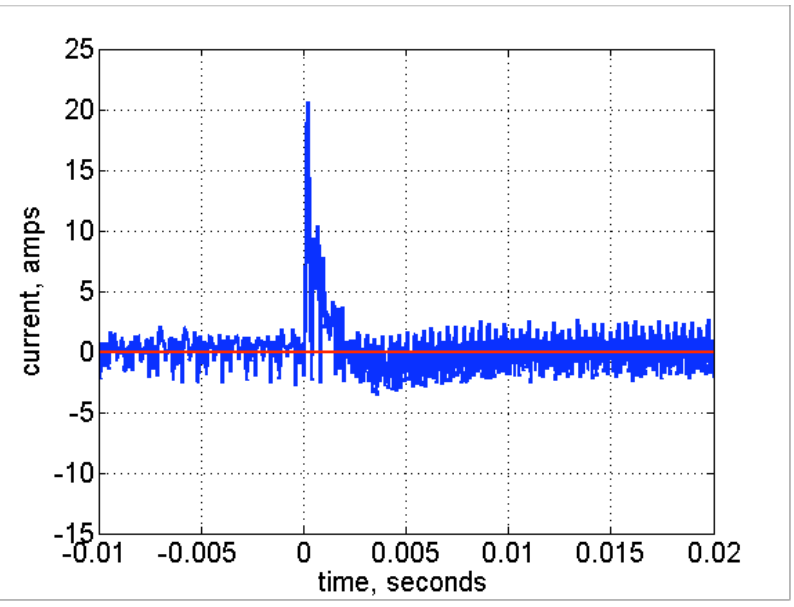

Figure 22. Expanded Motor d-axis Current Response at 50 kRPM with Filter Gains. 
Figs. 6 and 7. The cross-coupling causes the d-axis current to exhibit a response to a q-axis change and the q-axis current to exhibit a response to a d-axis change. For a perfectly decoupled system, a change in the q-axis current should cause no change in the d-axis.

\section{Back EMF Decoupling}

The current response can be improved by designing the current regulator using the complete motor model instead of the simple R-L model previously given in Eqs. (4) and (5). The complete state equations are given in (14) and (15) for the permanent magnet machine modeled in the rotor reference frame [5].

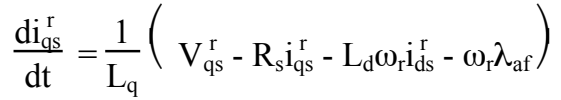

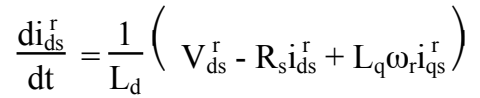

In addition to the resistance and inductance terms of the simple R-L model, there is now a cross-coupling term in each equation that is dependent on the inductance, the speed and the current in the other axis. In addition, there is the back EMF term in the q-axis equation, $\square_{\mathrm{r}} \square_{\mathrm{af}}$, that represents the voltage produced by the rotor magnets as they rotate through the stator windings.

The effect of the cross-coupling can be removed by adding terms to the current regulator that anticipate and approximately cancel the coupling terms using a technique known as back EMF decoupling [5]. If the motor parameters are known exactly, the result of back EMF decoupling is to reduce the motor state equations to the simple R-L model given earlier in Eqs. (4) and (5). This is shown in (16) and (17) where the ${ }^{\wedge}$ symbol indicates the estimated value of the parameter. The block diagram of the total system, current regulator and motor model, is shown in Fig. 23. The right half of the block diagram is the motor model and the left half is the current regulator with back EMF decoupling. The gain values, $\mathrm{K}_{\mathrm{p}}$ and $\mathrm{K}_{\mathrm{i}}$, remain the same as given in Table 2 .

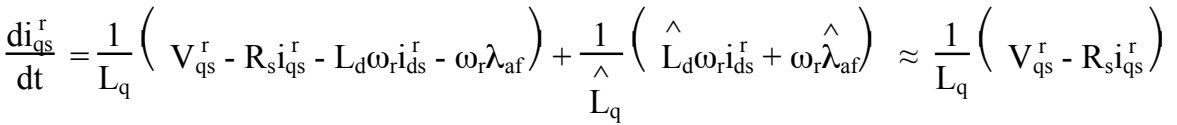

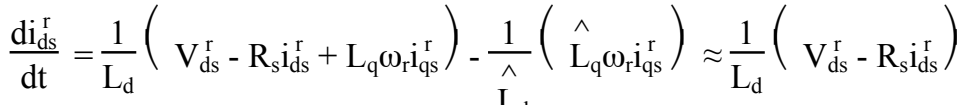

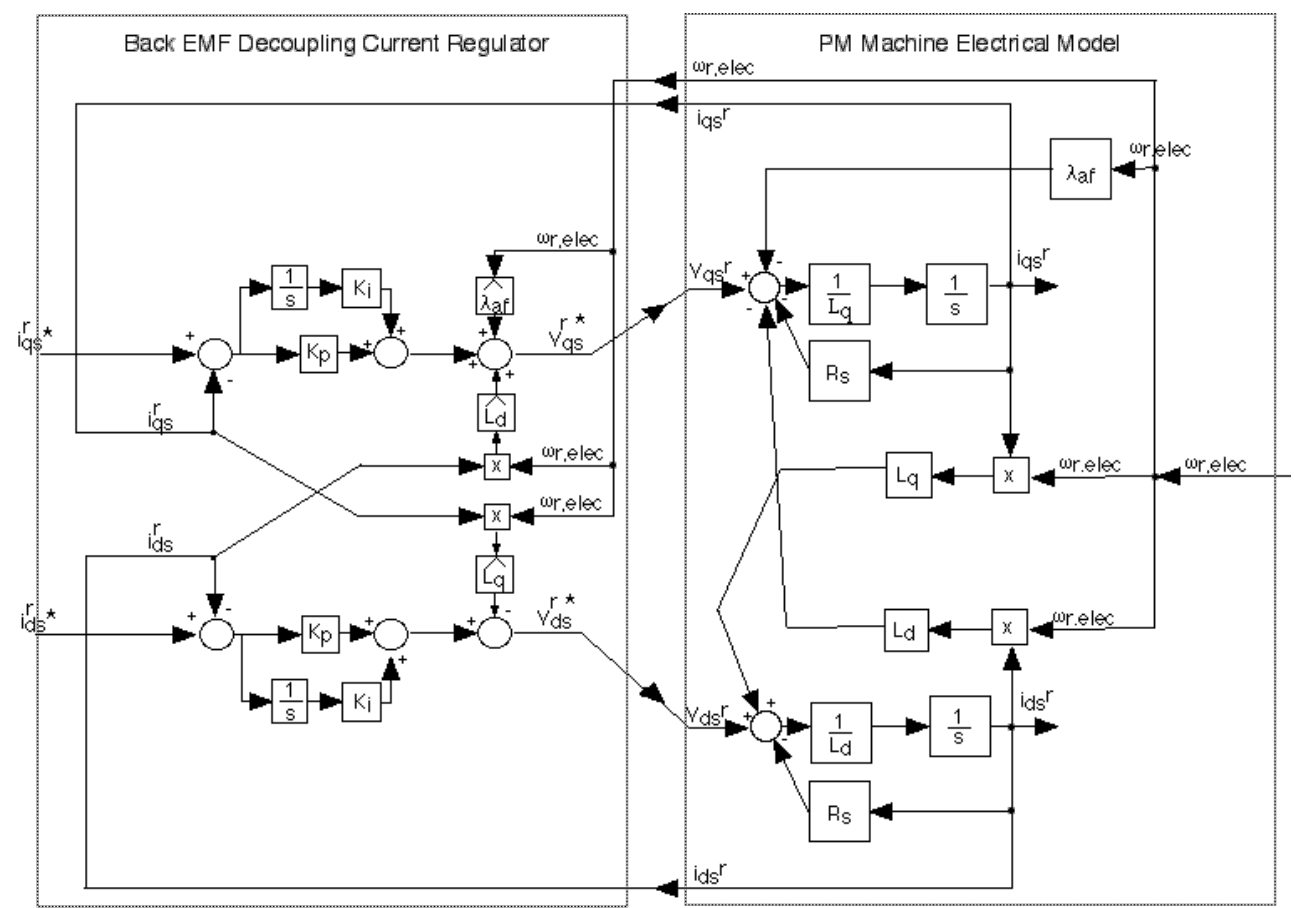

Figure 23. Back EMF Current Regulator and PM Motor Modeled in the Rotor Reference Frame. 


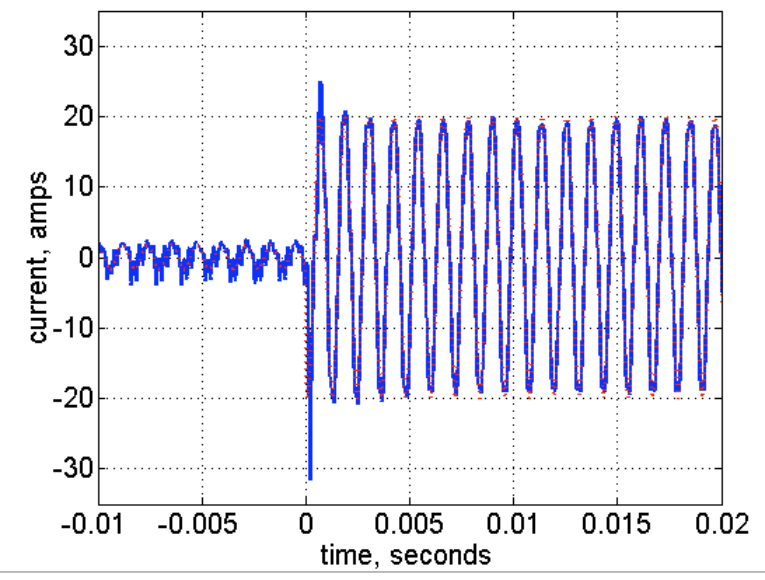

Figure 24. Motor Phase Current Response at 50 kRPM, with Filter Gains and Back EMF Decoupling.

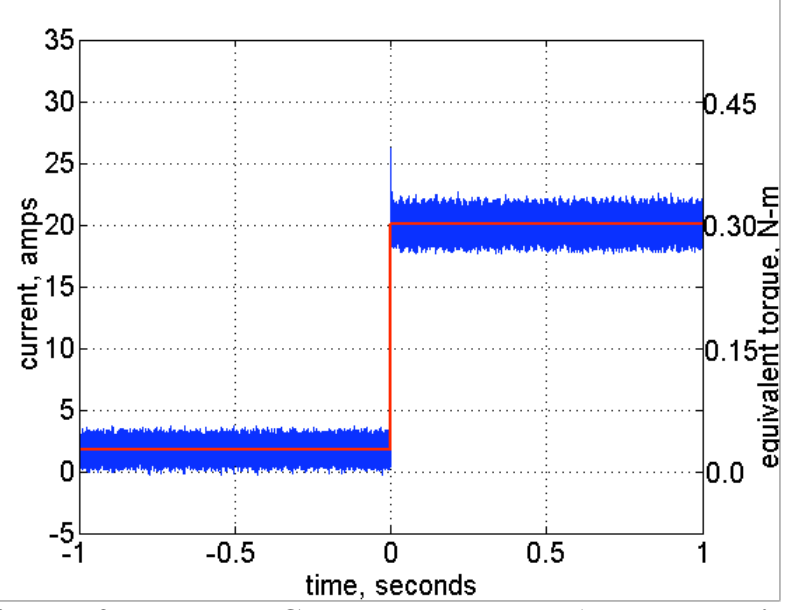

Figure 25. Motor Commanded and Actual q-axis Current and Equivalent Torque at $50 \mathrm{kRPM}$ with Filter Gains and Back EMF Decoupling.

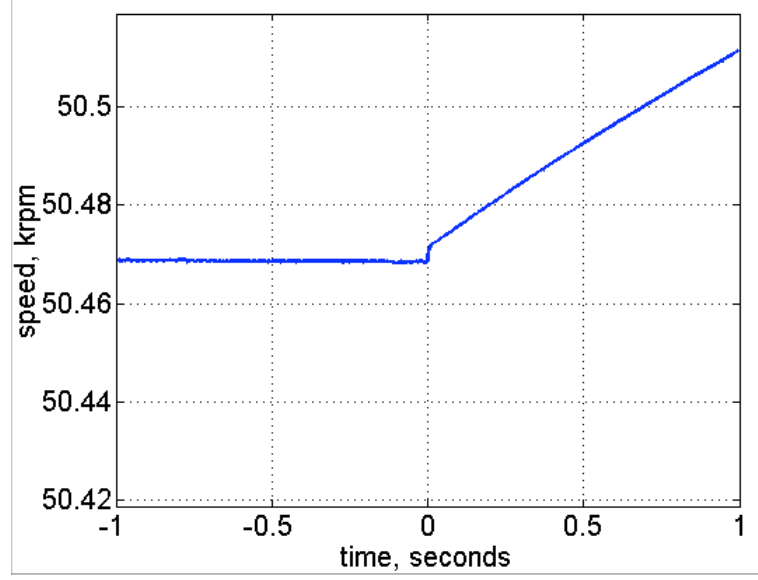

Figure 27. Motor Speed during transient at $50 \mathrm{kRPM}$ with Filter Gains and Back EMF Decoupling.
The results using the controller with the back EMF decoupling added are shown in Figs. 24 through 28. The flywheel speed is 50,000 rpm and the gains are the same as for the results shown in Figs. 18 through 22. The decoupling current regulator reduces the d-axis overshoot as can be seen by comparing Fig. 28 to Fig. 22. In addition, the q-axis current peak is also reduced as shown in Fig. 26 versus Fig. 20. However, Fig. 24 shows a greater phase current overshoot than in Fig. 18 in spite of the improvements seen in the d- and q-axes. In the ideal case, an improvement in the q- and d-axis response should lead to a corresponding improvement in the phase current response.

The most likely explanation for this discrepancy is that there is an error between the actual and estimated rotor angle, $\hat{\square}_{r}$, that is used in the reference frame transformations necessary for the field orientation

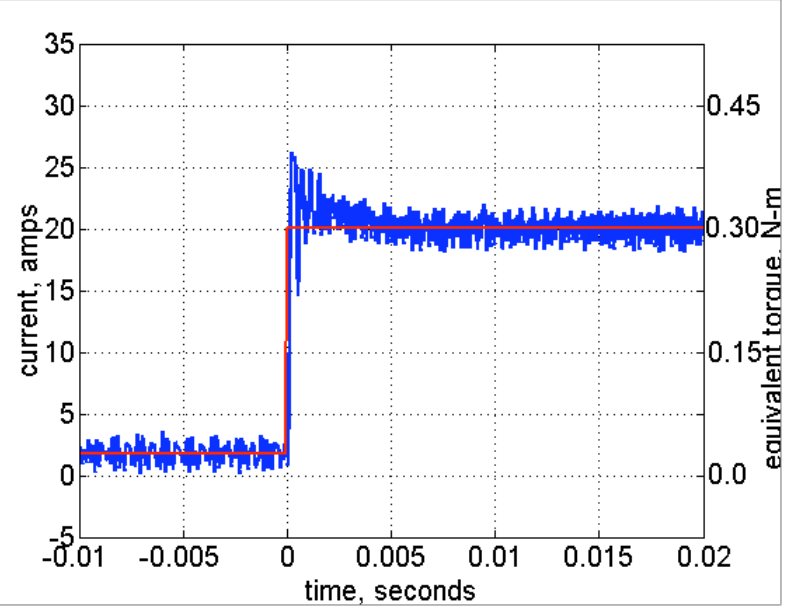

Figure 26. Expanded Motor q-axis Current Response at 50 kRPM with Filter Gains and Back EMF Decoupling.

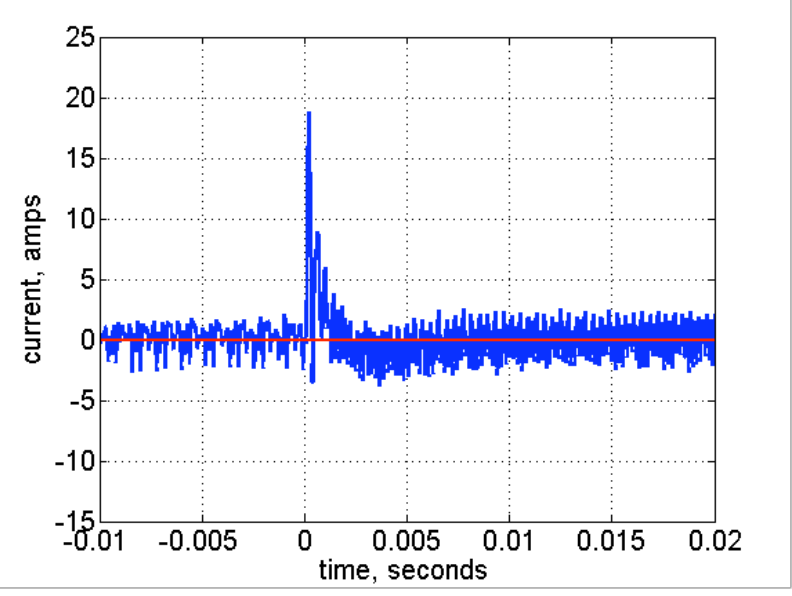

Figure 28. Expanded Motor d-axis Current Response at 50 kRPM with Filter Gains and Back EMF Decoupling. 
control technique. The estimated rotor angle is based primarily on the assumption that the commanded voltage, $\mathbf{V}_{\text {qds }}^{\mathrm{s}^{*}}$, is equal to the actual motor phase voltage [6]. However, the filter adds additional impedance between the inverter and the motor as already described. This impedance has an associated phase lag that adds to the controller sampling and processing time lag. The total phase shift will appear directly as an error in the estimation of the rotor position angle, $\hat{\square}$. The result of using an inaccurate rotor angle is to introduce additional coupling between the $\mathrm{d}$ - and q-axis in the torque response of the machine and also to deviate from the most efficient (measured as maximum torque per amp) operating point. Identifying and quantifying the impact of rotor angle estimation errors is an area of future work.

\section{DC Bus Voltage Limit}

As discussed in Section III, the motor control is based on the assumption that the transfer function between the commanded voltage and the output fundamental voltage from the inverter is equal to 1 . This is true as long as the commanded voltage is less than the maximum value given in Eq. (7). In the flywheel system with a DC bus voltage of 125 volts, the maximum peak value is 72 volts, line to neutral. This peak value ultimately limits the speed of the machine because as the speed increases, so does the required motor phase voltage. This can be seen from the motor state equations given in Eqs. (14) and (15) rearranged to see the necessary voltage for various operating conditions as shown in Eqs. (18) and (19). Equation (20) describes the peak phase voltage magnitude.

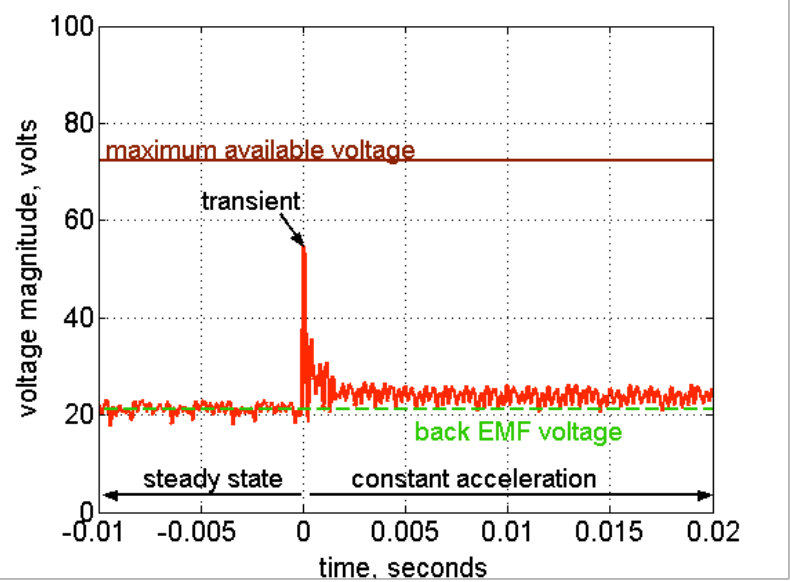

Figure 29. Commanded Phase Voltage During Step Change in Current Command at 20 kRPM.

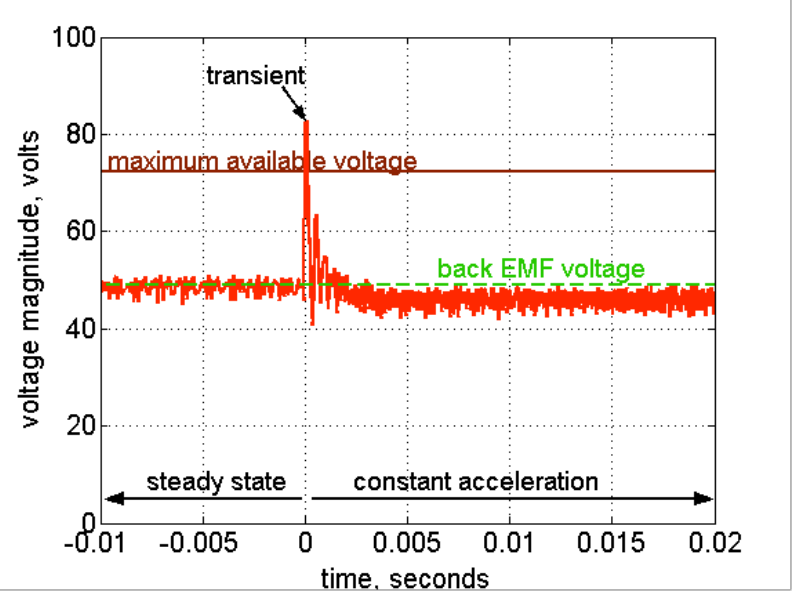

Figure 30. Commanded Phase Voltage During Step Change in Current Command at 50 kRPM.

$$
\begin{gathered}
\mathrm{V}_{\mathrm{qs}}^{\mathrm{r}}=\mathrm{R}_{\mathrm{s}} \mathrm{i}_{\mathrm{qs}}^{\mathrm{r}}+\mathrm{L}_{\mathrm{d}} \square_{\mathrm{r}} \mathrm{i}_{\mathrm{ds}}^{\mathrm{r}}+\square_{\mathrm{r}} \square_{\mathrm{af}}+\mathrm{L}_{\mathrm{q}} \frac{\mathrm{di}_{\mathrm{qs}}^{\mathrm{r}}}{\mathrm{dt}} \\
\mathrm{V}_{\mathrm{ds}}^{\mathrm{r}}=\mathrm{R}_{\mathrm{s}} \mathrm{i}_{\mathrm{ds}}^{\mathrm{r}}-\mathrm{L}_{\mathrm{q}} \square_{\mathrm{r}} \mathrm{i}_{\mathrm{qs}}^{\mathrm{r}}+\mathrm{L}_{\mathrm{d}} \frac{\mathrm{di} \mathrm{d}_{\mathrm{ds}}^{\mathrm{r}}}{\mathrm{dt}} \\
\left|\mathrm{V}_{\mathrm{qds}}^{\mathrm{r}}\right|=\sqrt{\left(\mathrm{V}_{\mathrm{qs}}^{\mathrm{r}}\right)^{2}+\left(\mathrm{V}_{\mathrm{ds}}^{\mathrm{r}}\right)^{2}}
\end{gathered}
$$

For steady state operation (constant speed), the derivative terms in (18) and (19) become zero. The commanded d-axis current is zero and if the rotor angle used in the reference frame transformation is correct, the actual d-axis current will also be zero and thus the $\mathrm{i}_{\mathrm{ds}}^{\mathrm{r}}$ terms will be equal to zero in the equations. The voltage equations then reduce to Eqs. (21) and (22).

$$
\begin{array}{r}
\mathrm{V}_{\mathrm{qs}}^{\mathrm{r}}=\mathrm{R}_{\mathrm{s}} \mathrm{i}_{\mathrm{qs}}^{\mathrm{r}}+\square_{\mathrm{r}} \square_{\mathrm{af}} \\
\mathrm{V}_{\mathrm{ds}}^{\mathrm{r}}=-\mathrm{L}_{\mathrm{q}} \square_{\mathrm{r}} \mathrm{i}_{\mathrm{qs}}^{\mathrm{r}}
\end{array}
$$

It can be seen from Eqs. (21) and (22) that at steady state, the magnitude of the voltage applied to the machine will be dominated by the back EMF voltage (the $\square_{\mathrm{r}} \square_{\mathrm{af}}$ term). This is because the voltage drop across the motor resistance in Eq. (21) and the voltage drop across the inductance in Eq. (22) are small compared to the back EMF voltage, particularly at high speeds. During a step change in the current command, however, the voltage magnitude will increase sharply due to the non-zero value of the derivative term in Eq. (18). After the step, during the acceleration of the machine, the voltage magnitude will continue to be higher than in steady state because the current, $i_{\mathrm{q} s}^{\mathrm{r}}$, increases to provide the torque necessary for acceleration.

The voltage magnitude during the steady state, the step change transient, and the acceleration phases can be seen in Figs. 29 and 30 for 20,000 RPM and 50,000 RPM operation, respectively. Both plots are for a $2 \mathrm{kHz}$ bandwidth system using back EMF decoupling and the gains given in Table 3 (with the filter of Fig. 3). In addition, Fig. 30 corresponds to the same test run as reported in Figs. 24 to 28. It can be seen from the figures that the voltage spike 
due to the step change in the current command at time $\mathrm{t}=0$ is within the maximum available voltage for 20,000 RPM operation but exceeds it for approximately a millisecond for 50,000 RPM operation. During this time, the inverter provides the maximum voltage possible but cannot provide the commanded value. However, the current is able to eventually reach the correct operating point even though the commanded voltage is not available for the first millisecond of the transient.

It can also be seen from the figures that for the 20,000 RPM operation case, the voltage magnitude behaves as described above: close to the back EMF voltage at steady state $(t<0)$ and slightly higher than the back EMF voltage during acceleration $(t>0)$. For the 50,000 RPM case, the voltage magnitude is approximately equal to the back EMF voltage in steady state but it clearly decreases during acceleration. This would seem to contradict the explanation given above, however, that derivation is based on the assumption that the reference frame transformations are accomplished correctly through accurate knowledge of the rotor angle. In the present implementation of the controller, a phase lag between the commanded voltage and the voltage applied to the motor would cause a rotor angle estimate that lags the actual angle and results in a non-zero (negative) $i_{\mathrm{ds}}^{\mathrm{r}}$ term. A negative $\mathrm{i}_{\mathrm{ds}}^{\mathrm{r}}$ will reduce the voltage magnitude as can be seen from Eqs. (18), (19) and (20). This is the most likely cause of the voltage magnitude reduction observed in Fig. 30. As stated previously, work is presently underway to improve the rotor angle estimate and quantify any errors, particularly at high speeds, and it is expected that a more accurate estimate will resolve the discrepancies between the expected and measured behavior. It is interesting to note, however, that the controller still continues to provide an excellent overall response in spite of the suspected rotor angle estimation error.

Returning to the problem of the commanded voltage exceeding the available voltage, one possible solution is to limit the value of the derivative term in Eq. (18) by limiting the rate of change of the commanded current. If a 2 $\mathrm{kHz}$ response is desired, it is not necessary to change the current command in a step fashion but rather limit it to a ramp function that represents a command change within $2 \mathrm{kHz}$. Figures 31 through 36 show the results for a $2 \mathrm{kHz}$ bandwidth response, tuned with the gains of Table 3, and a $60 \mathrm{kA} / \mathrm{sec}$ ramp for the commanded value of current, $\mathrm{i}_{\mathrm{qs}}^{\mathrm{r}^{*}}$, as it transitions from 1.5 to 20 amps. This means that the derivative term in Eq. (18), $\frac{\mathrm{di}_{\mathrm{gs}}^{\mathrm{r}}}{\mathrm{dt}}$, will be approximately equal to $60 \mathrm{kA} / \mathrm{sec}$. Figure 31 shows the peak voltage command to be significantly less than the case without the ramp command and now well below the maximum available voltage. In addition, the current response is improved. There is less overshoot on the d-axis current (Fig. 36) and the q-axis current shown in Fig. 34 still has a $2 \mathrm{kHz}$ response with an approximate settling time of $2 \mathrm{msec}$ (a shorter time than the results without the ramp limit).

\section{Conclusions}

This paper has presented a discussion of the tuning techniques used for the current regulator of the NASA GRC flywheel system. The flywheel system electronics incorporate an AC filter between the inverter and the motor/generator to reduce the $\mathrm{dv} / \mathrm{dt}$ stress on the motor and to improve the magnetic bearing control. The AC filter adds additional dynamics to the system that must be considered when tuning the current regulator in order to achieve the desired performance at high speeds. The current regulator was initially tuned without consideration of the AC filter and the results were satisfactory at low speeds. However, as the speed increased, the response to a step change in current command was found to be more and more oscillatory. The oscillations were eliminated and a fast response was achieved when the current regulator gains were changed to include the impedance of the AC filter. The response with the adjusted gains was improved further by augmenting the current regulator with a back EMF decoupling portion and limiting the rate of change of the commanded current. A step change in current command is not a realistic command trajectory and limiting the current command to a ramp achieves the desired bandwidth with less overshoot and settling time. The ramped command also reduces the voltage command overshoot during the transient thus ensuring that the commanded voltage can be achieved at all times.

A few discrepancies were noted that were most likely caused by an error in the estimated rotor position. Adding back EMF decoupling to the current regulator did not reduce the transient overshoot in the actual phase current even though it was reduced in the q- and d-axes. For a perfect transformation, the phase current transient would have also been reduced. Additionally, the commanded voltage was lower than the back EMF voltage at high speeds during acceleration. Again, with perfect transformation using the exact rotor position angle, the commanded voltage is expected to be higher than the back EMF voltage during acceleration. Quantifying and correcting the suspected rotor position estimation error is the next step for the improvement of the flywheel motor/generator control.

However, the overall goal of achieving current regulation with a $2 \mathrm{kHz}$ bandwidth for speeds up to 50,000 RPM was achieved and documented. This type of current response enables the high performance torque control necessary for the flywheel operation at all speeds. 


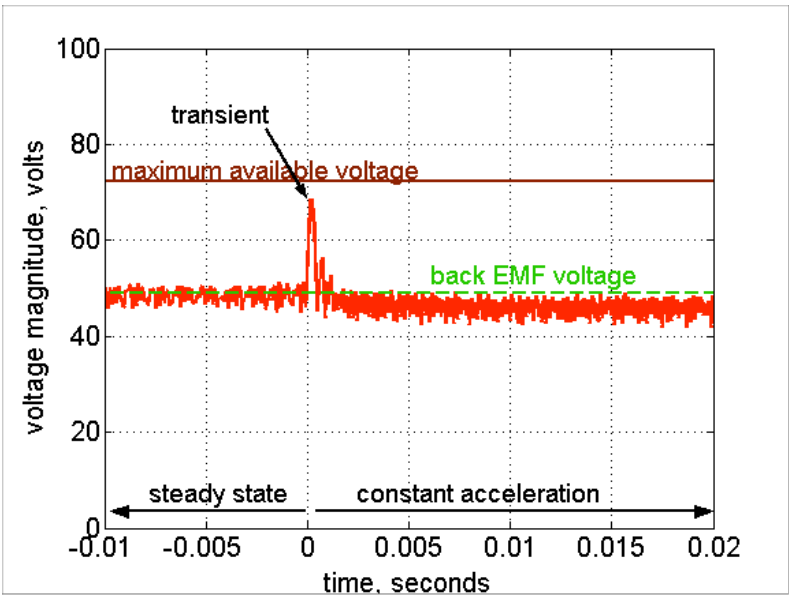

Figure 31. Commanded Phase Voltage During Step Change in Current Command with $60 \mathrm{kA} / \mathrm{sec}$ Rate Limit.

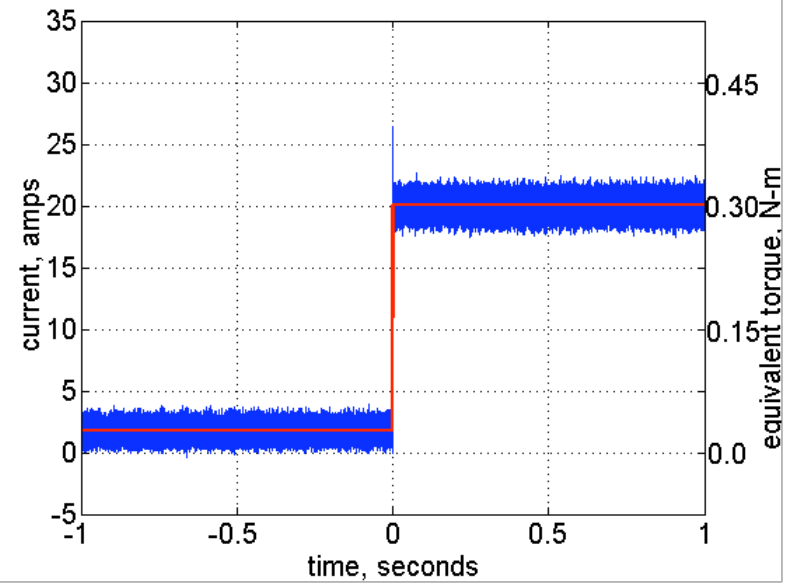

Figure 33. Motor q-axis Current with $60 \mathrm{kA} / \mathrm{sec}$ Rate Limit.

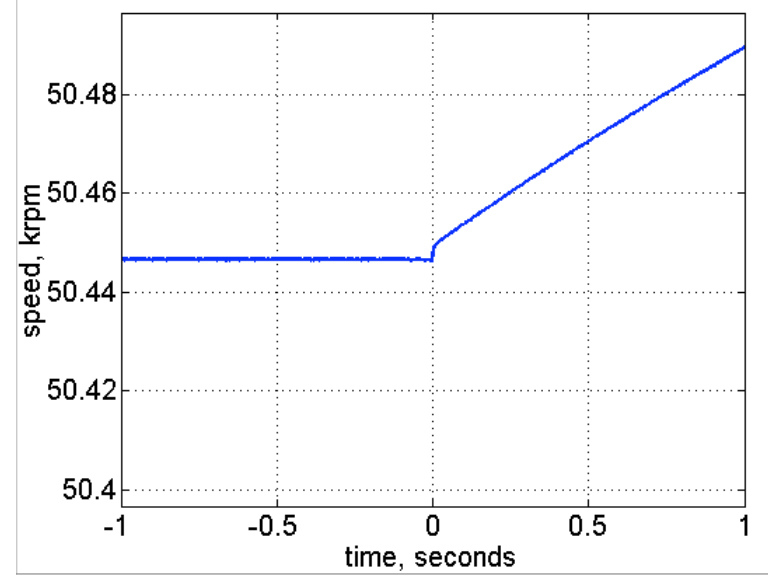

Figure 35. Motor Speed During Step Change in Current Command with $60 \mathrm{kA} / \mathrm{sec}$ Rate Limit.

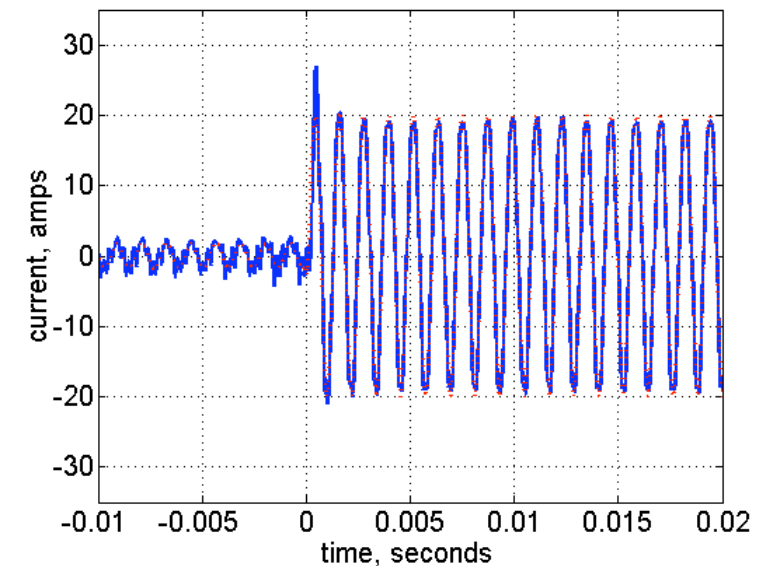

Figure 32. Motor Phase Current with $60 \mathrm{kA} / \mathrm{sec}$ Rate Limit at 50,000 RPM.

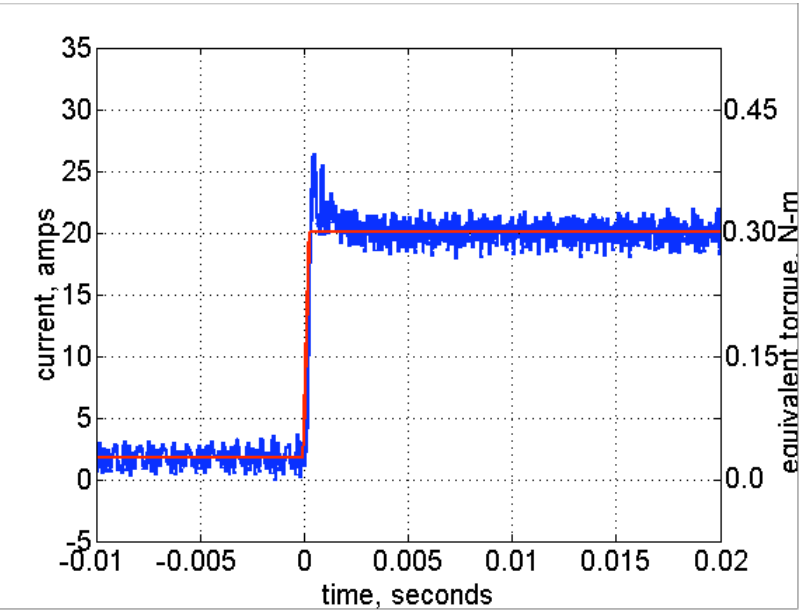

Figure 34. Magnified View of Motor q-axis Current with 60 kA/sec Rate Limit.

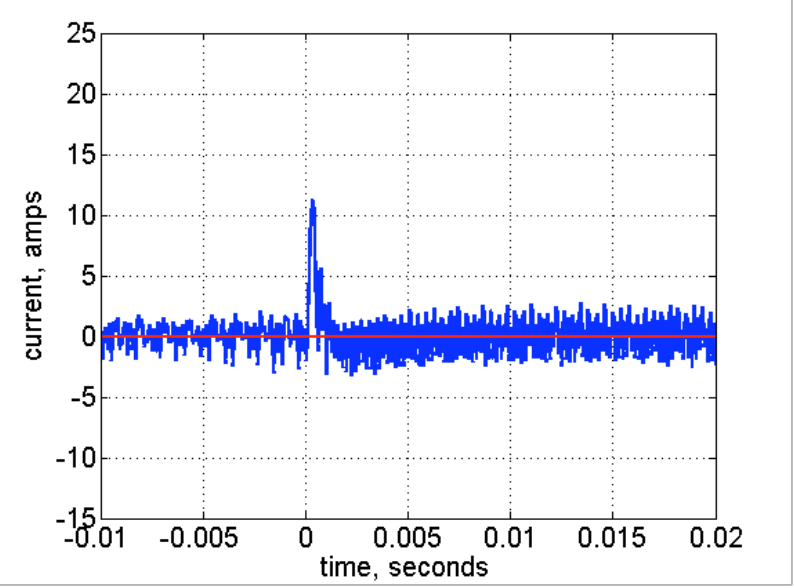

Figure 36. Magnified View of Motor d-axis Current with 60 kA/sec Rate Limit.. 


\section{Appendix}

The Thevenin equivalent circuit was calculated for the filter shown in Fig. 3. The results are given below where

$\mathrm{V}_{\text {thev,numerator }}$ is the Thevenin voltage numerator, $\mathrm{V}_{\text {thev,denominator }}$ is the Thevenin voltage denominator, $\mathrm{Z}_{\text {thev,numerator }}$ is the Thevenin impedance numerator, and $Z_{\text {thev,denominator }}$ is the Thevenin impedance demoninator.

$$
\begin{aligned}
& \mathrm{V}_{\text {thev,numerator }}=\mathrm{s}^{3} \mathrm{R}_{2} \mathrm{C}_{2} \mathrm{~L}_{\mathrm{t}} \mathrm{C}_{\mathrm{t}}+\mathrm{s}^{2} \mathrm{~L}_{\mathrm{t}} \mathrm{C}_{\mathrm{t}}+\mathrm{sR}_{2} \mathrm{C}_{2}+1 \\
& \mathrm{~V}_{\text {thev,denominator }}=\mathrm{s}^{6} \mathrm{C}_{1} \mathrm{C}_{2} \mathrm{~L}_{1} \mathrm{~L}_{2} \mathrm{C}_{\mathrm{t}} \mathrm{L}_{\mathrm{t}}+\mathrm{s}^{5} \mathrm{~L}_{1} \mathrm{C}_{1} \mathrm{R}_{2} \mathrm{C}_{2} \mathrm{~L}_{\mathrm{t}} \mathrm{C}_{\mathrm{t}}+\mathrm{s}^{4}\left(\mathrm{C}_{1} \mathrm{C}_{2} \mathrm{~L}_{1} \mathrm{~L}_{2}+\mathrm{L}_{2} \mathrm{C}_{2} \mathrm{~L}_{\mathrm{t}} \mathrm{C}_{\mathrm{t}}+\mathrm{L}_{1} \mathrm{C}_{2} \mathrm{~L}_{\mathrm{t}} \mathrm{C}_{\mathrm{t}}+\mathrm{L}_{1} \mathrm{C}_{1} \mathrm{~L}_{\mathrm{t}} \mathrm{C}_{\mathrm{t}}\right)+ \\
& \mathrm{s}^{3}\left(\mathrm{~L}_{1} \mathrm{C}_{1} \mathrm{R}_{2} \mathrm{C}_{2}+\mathrm{R}_{2} \mathrm{C}_{2} \mathrm{~L}_{\mathrm{t}} \mathrm{C}_{\mathrm{t}}\right)+\mathrm{s}^{2}\left(\mathrm{~L}_{\mathrm{t}} \mathrm{C}_{\mathrm{t}}+\mathrm{L}_{2} \mathrm{C}_{2}+\mathrm{L}_{1} \mathrm{C}_{2}+\mathrm{L}_{1} \mathrm{C}_{1}+\mathrm{L}_{\mathrm{t}} \mathrm{C}_{2}\right)+\mathrm{s}\left(\mathrm{R}_{2} \mathrm{C}_{2}\right)+1 \\
& \mathrm{Z}_{\text {thev,numerator }}=\mathrm{s}^{6}\left(\mathrm{C}_{1} \mathrm{C}_{2} \mathrm{C}_{\mathrm{t}} \mathrm{L}_{1} \mathrm{~L}_{2} \mathrm{~L}_{\mathrm{t}} \mathrm{R}_{2}\right)+\mathrm{s}^{5}\left(\mathrm{C}_{1} \mathrm{C}_{\mathrm{t}} \mathrm{L}_{1} \mathrm{~L}_{2} \mathrm{~L}_{\mathrm{t}}\right)+\mathrm{s}^{4}\left(\mathrm{C}_{2} \mathrm{C}_{\mathrm{t}} \mathrm{L}_{1} \mathrm{~L}_{\mathrm{t}} \mathrm{R}_{2}+\mathrm{C}_{2} \mathrm{C}_{\mathrm{t}} \mathrm{L}_{2} \mathrm{~L}_{\mathrm{t}} \mathrm{R}_{2}+\mathrm{C}_{1} \mathrm{C}_{2} \mathrm{~L}_{2} \mathrm{~L}_{\mathrm{t}} \mathrm{R}_{2}+\mathrm{C}_{1} \mathrm{C}_{2} \mathrm{~L}_{1} \mathrm{~L}_{2} \mathrm{R}_{2}\right)+ \\
& \mathrm{s}^{3}\left(\mathrm{C}_{\mathrm{t}} \mathrm{L}_{1} \mathrm{~L}_{\mathrm{t}}+\mathrm{C}_{\mathrm{t}} \mathrm{L}_{2} \mathrm{~L}_{\mathrm{t}}+\mathrm{C}_{1} \mathrm{~L}_{2} \mathrm{~L}_{\mathrm{t}}+\mathrm{C}_{1} \mathrm{~L}_{1} \mathrm{~L}_{2}\right)+\mathrm{s}^{2}\left(\mathrm{C}_{2} \mathrm{~L}_{\mathrm{t}} \mathrm{R}_{2}+\mathrm{C}_{2} \mathrm{~L}_{1} \mathrm{R}_{2}+\mathrm{C}_{2} \mathrm{~L}_{2} \mathrm{R}_{2}\right)+\mathrm{s}\left(\mathrm{L}_{1}+\mathrm{L}_{2}+\mathrm{L}_{\mathrm{t}}\right) \\
& \mathrm{Z}_{\text {thev,denominator }}=\mathrm{s}^{6}\left(\mathrm{C}_{1} \mathrm{C}_{2} \mathrm{C}_{\mathrm{t}} \mathrm{L}_{1} \mathrm{~L}_{2} \mathrm{~L}_{\mathrm{t}}\right)+\mathrm{s}^{5}\left(\mathrm{C}_{1} \mathrm{C}_{2} \mathrm{C}_{\mathrm{t}} \mathrm{L}_{1} \mathrm{~L}_{\mathrm{t}} \mathrm{R}_{2}\right)+\mathrm{s}^{4}\left(\mathrm{C}_{2} \mathrm{C}_{\mathrm{t}} \mathrm{L}_{1} \mathrm{~L}_{\mathrm{t}}+\mathrm{C}_{1} \mathrm{C}_{2} \mathrm{~L}_{1} \mathrm{~L}_{2}+\mathrm{C}_{1} \mathrm{C}_{\mathrm{t}} \mathrm{L}_{1} \mathrm{~L}_{\mathrm{t}}+\mathrm{C}_{2} \mathrm{C}_{\mathrm{t}} \mathrm{L}_{2} \mathrm{~L}_{\mathrm{t}}+\mathrm{C}_{1} \mathrm{C}_{2} \mathrm{~L}_{2} \mathrm{~L}_{\mathrm{t}}\right)+ \\
& \mathrm{s}^{3}\left(\mathrm{C}_{1} \mathrm{C}_{2} \mathrm{~L}_{\mathrm{t}} \mathrm{R}_{2}+\mathrm{C}_{2} \mathrm{C}_{\mathrm{t}} \mathrm{L}_{\mathrm{t}} \mathrm{R}_{2}+\mathrm{C}_{1} \mathrm{C}_{2} \mathrm{~L}_{1} \mathrm{R}_{2}\right)+\mathrm{s}^{2}\left(\mathrm{~L}_{\mathrm{t}} \mathrm{C}_{2}+\mathrm{L}_{\mathrm{t}} \mathrm{C}_{\mathrm{t}}+\mathrm{C}_{1} \mathrm{~L}_{\mathrm{t}}+\mathrm{C}_{1} \mathrm{~L}_{1}+\mathrm{C}_{2} \mathrm{~L}_{2}+\mathrm{C}_{2} \mathrm{~L}_{1}\right)+\mathrm{sC}_{2} \mathrm{R}_{2}+1
\end{aligned}
$$

For the filter without the L-C trap, the Thevenin values are as follows.

$$
\begin{gathered}
\mathrm{V}_{\text {thev,no L-C trap }}=\frac{\mathrm{sR}_{2} \mathrm{C}_{2}+1}{\mathrm{~s}^{4}\left(\mathrm{C}_{1} \mathrm{C}_{2} \mathrm{~L}_{1} \mathrm{~L}_{2}\right)+\mathrm{s}^{3}\left(\mathrm{~L}_{1} \mathrm{C}_{1} \mathrm{R}_{2} \mathrm{C}_{2}\right)+\mathrm{s}^{2}\left(\mathrm{~L}_{2} \mathrm{C}_{2}+\mathrm{L}_{1} \mathrm{C}_{2}+\mathrm{L}_{1} \mathrm{C}_{1}\right)+\mathrm{s}\left(\mathrm{R}_{2} \mathrm{C}_{2}\right)+1} \\
\mathrm{Z}_{\text {thev,no L-C trap }}=\frac{\mathrm{s}^{4}\left(\mathrm{C}_{2} \mathrm{C}_{1} \mathrm{~L}_{1} \mathrm{~L}_{2} \mathrm{R}_{2}\right)+\mathrm{s}^{3}\left(\mathrm{C}_{1} \mathrm{~L}_{1} \mathrm{~L}_{2}\right)+\mathrm{s}^{2}\left(\mathrm{C}_{2} \mathrm{~L}_{1} \mathrm{R}_{2}+\mathrm{C}_{2} \mathrm{~L}_{2} \mathrm{R}_{2}\right)+\mathrm{s}\left(\mathrm{L}_{1}+\mathrm{L}_{2}\right)}{\mathrm{s}^{4}\left(\mathrm{C}_{1} \mathrm{C}_{2} \mathrm{~L}_{1} \mathrm{~L}_{2}\right)+\mathrm{s}^{3}\left(\mathrm{C}_{1} \mathrm{C}_{2} \mathrm{~L}_{1} \mathrm{R}_{2}\right)+\mathrm{s}^{2}\left(\mathrm{C}_{1} \mathrm{~L}_{1}+\mathrm{C}_{2} \mathrm{~L}_{2}+\mathrm{C}_{2} \mathrm{~L}_{1}\right)+\mathrm{sC}_{2} \mathrm{R}_{2}+1}
\end{gathered}
$$

\section{References}

${ }^{1}$ Kenny, Barbara H.; Kascak, Peter E.; Jansen, Ralph; Dever, Timothy; “A Flywheel Energy Storage System Demonstration for Space Applications." NASA/TM-2003-212346, Proceedings of the International Electric Machines and Drives Conference Madison, Wisconsin, June 1-4, 2003.

${ }^{2}$ Kenny, Barbara H., Kascak, Peter E., Jansen, Ralph, Dever, Timothy and Santiago, Walter, "Demonstration of Single Axis Combined Attitude Control and Energy Storage Using Two Flywheels," NASA/TM-2004-212935, Proceedings of the 2004 IEEE Aerospace Conference [CD ROM], Big Sky, Montana, March 6-13, 2004.

${ }^{3}$ Kascak, Peter E., Jansen, Ralph, Kenny, Barbara H. and Dever, Timothy, "Demonstration of Single Axis Spacecraft Angle Control and DC Bus Regulation with Two Flywheel Energy Storage Units," accepted for publication at the IEEE Industry Applications Society (IAS) Annual Meeting, Seattle, Washington, October, 2004.

${ }^{4}$ Kenny, Barbara H., Kascak, P., Hofmann, H., Mackin, M., Santiago, W., and Jansen, R., “Advanced Motor Control Test Facility for NASA GRC Flywheel Energy Storage System Technology Development Unit," NASA/TM-2001-210986, Proceedings of the 2001 Intersociety Energy Conversion Engineering Conference [CD ROM], Savannah, GA, July 29- Aug. 2, 2001.

${ }^{5}$ Ramu, Krishnan, Permanent Magnet Synchronous and Brushless DC Motor Drives: Theory, Operation, Performance, Modeling, Simulation, Analysis and Design, Virginia Polytechnical Institute, Blacksburg, Va., 1999.

${ }^{6}$ Kenny, Barbara H., and Kascak, P., "Sensorless Control of Permanent Magnet Machine for NASA Flywheel Technology Development", NASA/TM-2002-211726, Proceedings of the 2002 Intersociety Energy Conversion Engineering Conference [CD ROM], Washington, D.C., July 28- Aug. 2, 2002.

${ }^{7}$ Kenny, Barbara H., Kascak, Peter E., Jansen, Ralph, Dever, Timothy and Santiago, Walter, "Control of a High Speed Flywheel System for Energy Storage in Space Applications," Pending NASA/TM (2004-XXXXXX) publication.

${ }^{8}$ Kenny, Barbara H., "Motor Control of Two Flywheels Enabling Combined Attitude Control and Bus Regulation," Conference Presentation, 2004 Space Power Workshop, Manhattan Beach, CA., April 19-22, 2004.

${ }^{9}$ Santiago, Walter, "Inverter Output Filter Effect on PWM Motor Drives of a Flywheel Energy Storage System," accepted for publication at the $2^{\text {nd }}$ International Energy Conversion Engineering Conference, Providence, RI., August 16-19, 2004.

${ }^{10}$ Rowan, T. and R. Kerkman, "A New Synchronous Current Regulator and an Analysis of Current-Regulated PWM Inverters," IEEE Transactions on Industry Applications, Vol IA-22, No. 4, July/August 1986, pp. 678-690.

${ }^{11}$ Holtz, Joachim, "Pulsewidth Modulation for Electronic Power Conversion," Proceedings of the IEEE, Volume 82, No. 8, August, 1994, pp. 1194-1214. 
Public reporting burden for this collection of information is estimated to average 1 hour per response, including the time for reviewing instructions, searching existing data sources, gathering and maintaining the data needed, and completing and reviewing the collection of information. Send comments regarding this burden estimate or any other aspect of this collection of information, including suggestions for reducing this burden, to Washington Headquarters Services, Directorate for Information Operations and Reports, 1215 Jefferson Davis Highway, Suite 1204, Arlington, VA 22202-4302, and to the Office of Management and Budget, Paperwork Reduction Project (0704-0188), Washington, DC 20503.

\begin{tabular}{|l|l|l} 
1. AGENCY USE ONLY (Leave blank) & $\begin{array}{c}\text { 2. REPORT DATE } \\
\text { October } 2004\end{array}$ & $\begin{array}{c}\text { 3. REPORT TYPE AND DATES COVERED } \\
\text { Technical Memorandum }\end{array}$
\end{tabular}

4. TITLE AND SUBTITLE 5. FUNDING NUMBERS

Filtering and Control of High Speed Motor Current in a Flywheel Energy Storage System

6. AUTHOR(S)

WBS-22-319-20-M1

Barbara H. Kenny and Walter Santiago

7. PERFORMING ORGANIZATION NAME(S) AND ADDRESS(ES)

National Aeronautics and Space Administration

John H. Glenn Research Center at Lewis Field

Cleveland, Ohio 44135-3191

8. PERFORMING ORGANIZATION REPORT NUMBER

E-14811

9. SPONSORING/MONITORING AGENCY NAME(S) AND ADDRESS(ES)

National Aeronautics and Space Administration

Washington, DC 20546-0001

10. SPONSORING/MONITORING AGENCY REPORT NUMBER

NASA TM-2004-213343

AIAA-2004-5627

\section{SUPPLEMENTARY NOTES}

Prepared for the Second International Energy Conversion Engineering Conference sponsored by the American Institute of Aeronautics and Astronautics, Providence, Rhode Island, August 16-19, 2004. Responsible person, Barbara H. Kenny, organization code 5450, 216-433-6289.

12a. DISTRIBUTION/AVAILABILITY STATEMENT

12b. DISTRIBUTION CODE

Unclassified - Unlimited

Subject Categories: 44 and 20

Distribution: Nonstandard

Available electronically at http://gltrs.grc.nasa.gov

This publication is available from the NASA Center for AeroSpace Information, 301-621-0390.

13. ABSTRACT (Maximum 200 words)

The NASA Glenn Research Center has been developing technology to enable the use of high speed flywheel energy storage units in future spacecraft for the last several years. An integral part of the flywheel unit is the three phase motor/generator that is used to accelerate and decelerate the flywheel. The motor/generator voltage is supplied from a pulse width modulated (PWM) inverter operating from a fixed DC voltage supply. The motor current is regulated through a closed loop current control that commands the necessary voltage from the inverter to achieve the desired current. The current regulation loop is the innermost control loop of the overall flywheel system and, as a result, must be fast and accurate over the entire operating speed range (20,000 to 60,000 rpm) of the flywheel. The voltage applied to the motor is a high frequency PWM version of the DC bus voltage that results in the commanded fundamental value plus higher order harmonics. Most of the harmonic content is at the switching frequency and above. The higher order harmonics cause a rapid change in voltage to be applied to the motor that can result in large voltage stresses across the motor windings. In addition, the high frequency content in the motor causes sensor noise in the magnetic bearings that leads to disturbances for the bearing control. To alleviate these problems, a filter is used to present a more sinusoidal voltage to the motor/generator. However, the filter adds additional dynamics and phase lag to the motor system that can interfere with the performance of the current regulator. This paper will discuss the tuning methodology and results for the motor/generator current regulator and the impact of the filter on the control. Results at speeds up to 50,000 rpm are presented.

14. SUBJECT TERMS

High speed motor control; Flywheel energy storage; Current regulation 15. NUMBER OF PAGES 20

\begin{tabular}{|c|c|c|}
\hline $\begin{array}{c}\text { 17. SECURITY CLASSIFICATION } \\
\text { OF REPORT } \\
\text { Unclassified }\end{array}$ & $\begin{array}{c}\text { 18. SECURITY CLASSIFICATION } \\
\text { OF THIS PAGE } \\
\text { Unclassified }\end{array}$ & $\begin{array}{c}\text { 19. SECURITY CLASSIFICATION } \\
\text { OF ABSTRACT } \\
\text { Unclassified }\end{array}$ \\
\hline
\end{tabular}



